\title{
Index Measurement and Influencing Factor Analysis of China's Financial Innovation Structure
}

\author{
Li Jian $^{1}$, Lin Wenhao ${ }^{2}$ \\ ${ }^{1}$ The School of Finance, Central University of Finance and Economics, Beijing, P. R. China \\ ${ }^{2}$ The School of Finance, Tianjin University of Finance and Economics, Tianjin, P. R. China
}

Email address:

lj@cufe.edu.cn(Li Jian), sub571@163.com (Lin Wenhao)

\section{To cite this article:}

Li Jian, Lin Wenhao. Index Measurement and Influencing Factor Analysis of China's Financial Innovation Structure. International Journal of Economics, Finance and Management Sciences. Vol. 7, No. 4, 2019, pp. 107-124. doi: 10.11648/j.ijefm.20190704.13

Received: September 29, 2018; Accepted: August 27, 2019; Published: September 9, 2019

\begin{abstract}
Since the reform and opening up in 1978, China has basically established a financial system that has adapted to the requirements of the market economy after several stages of financial innovation. Based on financial innovation events in China from 1979 to 2015, this paper compiles the structural index of China's financial innovation, and analyses the evolution trends and influencing factors of China's financial innovation structure. The index reflects the increasingly complexity and maturity of the overall structure of financial innovation since the reform and opening up, while the cumulative contribution of the six innovative forms to the changes in innovation structure has become more consistent and stable. The empirical analysis shows that the exploration of financial innovation is the continuous driving force to promote the change of financial innovation structure in China. What's more, major reform decisions, opening to the outside world, as well as scientific and technological progress promote the structural change of China's financial innovation, while the financial crisis inhibits the structural change of China's financial innovation. The policy implication of this paper is that China needs to deepen reform, create a more suitable environment for endogenous financial innovation, carry out more original financial innovation, focus on promoting system, management and technology innovation, and pay attention to the selection of opportunity and window period of innovation.
\end{abstract}

Keywords: Financial Innovation, Event Study Method, Structural Index of Financial Innovation, Influencing Factors of Innovation Structure

\section{Introduction}

Financial innovation is not only the primary force to lead the financial development, but also a continuous driving force for changing the financial structure. Since the mid-1970s, the global large-scale and all-round financial innovation has brought about profound changes in the financial structure. Then as of the beginning of reform and opening up in 1978, China has basically established a financial system that has adapted to the requirements of the market economy after several stages of financial innovation[1]. In the face of the endless financial innovation under the new market-oriented system in China, scholars not only should pay attention to the number of innovation events, but also should pay attention to the structure of financial innovation, namely, the distribution and proportion of financial innovations in various forms such as financial systems, institutions, markets, instruments, management and technology. Furthermore, because the financial innovation structure not only affects the structural change of the financial system, but also affects the function, efficiency and stability of the financial system [2], this paper researches on China's financial innovation from the perspective of structure in order to find out the evolution law of China's financial innovation structure, identify the influencing factors of financial innovation structure and explore the optimal path of financial innovation structure.

There are three challenges to studying the structure of financial innovation. First of all, financial innovation have diverse forms and different attributes so that a framework is needed to link various financial innovations in order to describe the structural characteristics of financial innovation at a specific point in time. For example, the financial innovation includes not only the original financial innovation 
"from 0 to 1 ", but also the duplicated and differentiated financial diffusion innovation "from 1 to $n$ ". Secondly, financial innovation events continue to emerge and promote each other during the transition period of China's economy. Therefore, it is necessary to record the structural change of financial innovation in a specific period of time with a dynamic process. Thirdly, the empirical method is used to identify the factors that affect the structure of financial innovation and to explore the ways to improve the structure of financial innovation.

At present, foreign scholars have used the financial liberalization index (that is, the financial marketization reform index) to describe the innovation status of financial system and empirically analyze the influencing factors of financial system innovation, such as Abiad and Mody [3]. This paper draws on this analytical idea to exponentially measure the structure of China's financial innovation since the reform and opening up, describe the structural change of financial innovation and empirically analyze the influencing factors of the financial innovation structure change.

The paper is organized as follows: The second part is literature review; In the second part, the index measurement of China's financial innovation structure reflects the structural characteristics and trends of financial innovation; The theoretical analysis of the factors affecting the change of financial innovation structure is the fourth part; The fifth part is about the empirical analysis of the influencing factors of financial innovation structure change; At last, the main conclusions and policy recommendations is in the sixth part.

\section{Literature Review}

Since Schumpeter proposed firstly the innovative theory in 1912, the academia often uses the innovation theory to study the classification, motivation and impact of the financial innovation. According to the definition of innovation concept in academia, the financial innovation can be defined as new things created or introduced in the financial field through the recombination of various elements and creative changes [4]. In addition, the main body of demand for the financial innovation benefits from overcoming market deficiencies as a demand-driven, profit-driven phenomenon. What's more, there must be supply entities that can respond to demand opportunities. At the same time, technological progress is also crucial. Furthermore, there are two other characteristics of the financial innovation: Firstly, the financial innovation is difficult to predict, and in fact it is rarely predicted. Secondly, the financial innovation can spread rapidly because of the relatively low cost of imitating, improving and differentiating the financial innovation.

Due to the variety of forms of the financial innovation, many famous people have classed it in different ways. For example, Finnerty [5] classified the financial innovation based on financial functions. Silber [6] advocated the classification or modeling of the causes of different forms of innovation, such as financial instruments, markets, and technologies. Persons and Warther [7] set up a model to explain the internal mechanism that financial innovation forms promote each other and present the spiral development characteristic. Bandiera, et al. [8], Kaminsky and Schmukler [9], as well as Abiad and Mody [3] believed that different forms and attributes of innovation events have different importance and influence on the basis of summarizing the events of financial system innovation, which should be classified and counted so that the index of financial system innovation can be compiled and then the origin or influence of financial system innovation should be analyzed empirically according to the index.

Since the 1970 s, economists have begun to pay attention to the influencing factors of the dynamic process of the financial innovation. For example, Ben-Horim and Silber [10], as well as Sametz [11] studied the determinants of the dynamic process of the financial innovation. In addition, relevant papers have found that many factors, such as the exploration process of financial innovation (Abiad and Mody, 2005), economic shocks such as crisis [12]; Eduardo and Mauricio [13], policy and legal system [14]; La Porta, et al. [15] and Levine, et al. [16], opening to the outside world [17, 18], and advances in science and technology, etc. will affect the occurrence of the financial innovation.

After the reform and opening up, many Chinese scholars [19-21] have studied the main course and influence of China's financial reform and innovation. Wang [22] pointed out that China's financial reform and innovation process needs to pay attention to the financial structure. Wang and yang [23] measured the financial innovation quality index and derived structural problems in China's financial innovation process based on international comparison.

From the perspective of research status and trends at home and abroad, few scholars have empirically studied the structural changes and influencing factors of China's financial innovation from a structural perspective. To this end, this paper attempts to innovate from the following aspects: Above of all, the financial innovation events from 1979 to 2015 are summarized and classified to establish a bank of financial innovation events. The second is to construct the structural index of Chinese financial innovation and analyze the structural characteristics of Chinese financial innovation by using research methods of Abiad and Mody [3], Bandiera, et al. [8], Laeven [24] and others. The third is to empirically analyze the influencing factors of financial innovation structure changes and propose relevant policy recommendations.

\section{Index Measurement of China's Financial Innovation Structure}

Based on the events of China's financial innovation from 1979 to 2015, this part uses the comprehensive evaluation method and the weighted arithmetic mean index method to measure the structure of China's financial innovation. What's more, the structural characteristics and changing trends of the financial innovation are analyzed from the aspects of overall structure and internal structure. 


\subsection{Chinese Financial Innovation Event Database: Innovation Classification and Statistics}

According to the definition of "financial innovation", this paper summarizes 589financial innovation events from 1979 to 2015 from Almanac of China's Finance and Banking
(1986-2015), literature on financial events, official website of Monetary and Regulatory Authority, as well as publications in order to establish a library of China's financial innovation events, which records in detail the specific events of China's financial innovation since the reform and opening up.

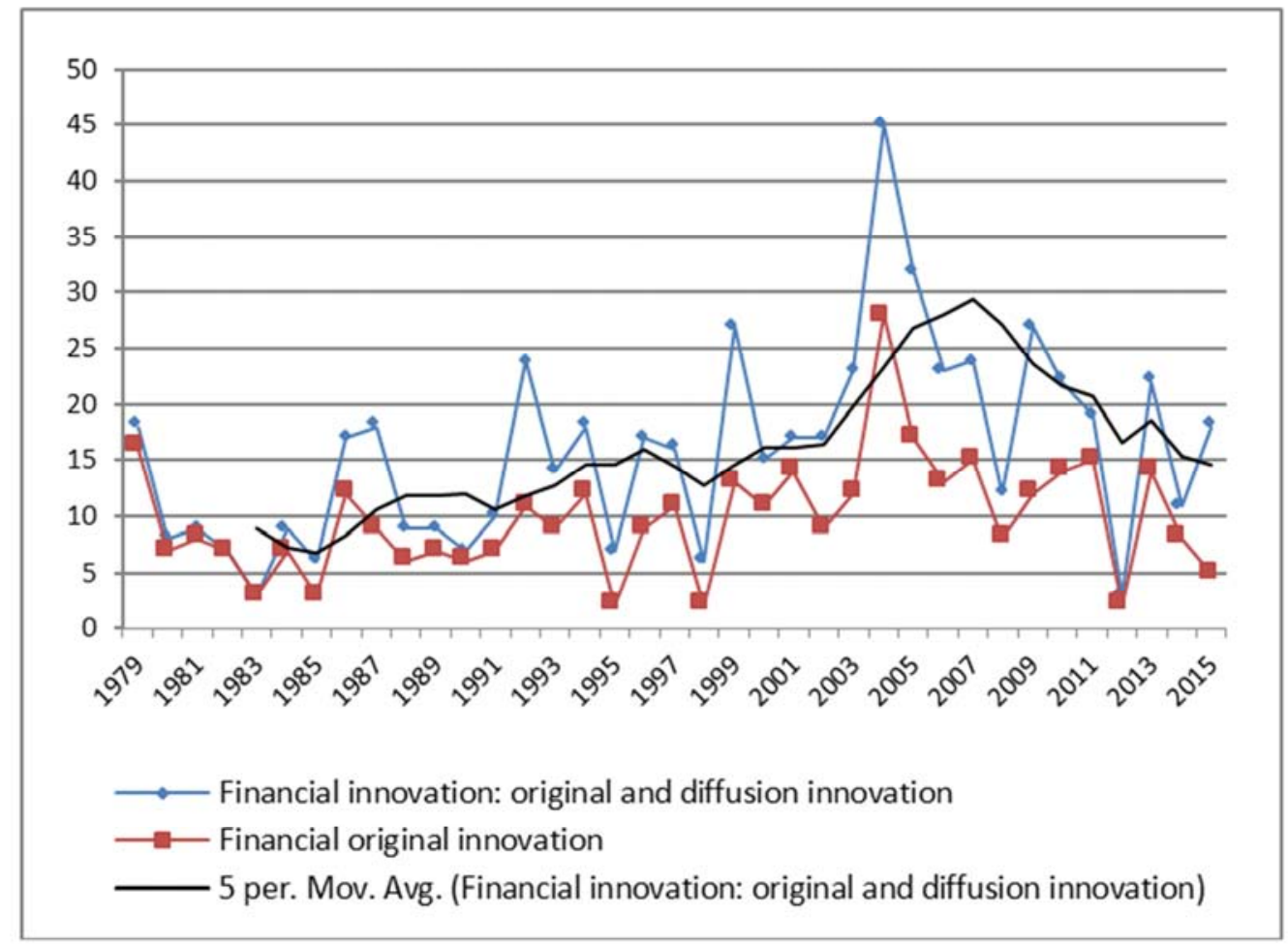

Figure 1. Number of financial innovation events (including 5-year moving average) and original financial innovation events from 1979 to 2015.

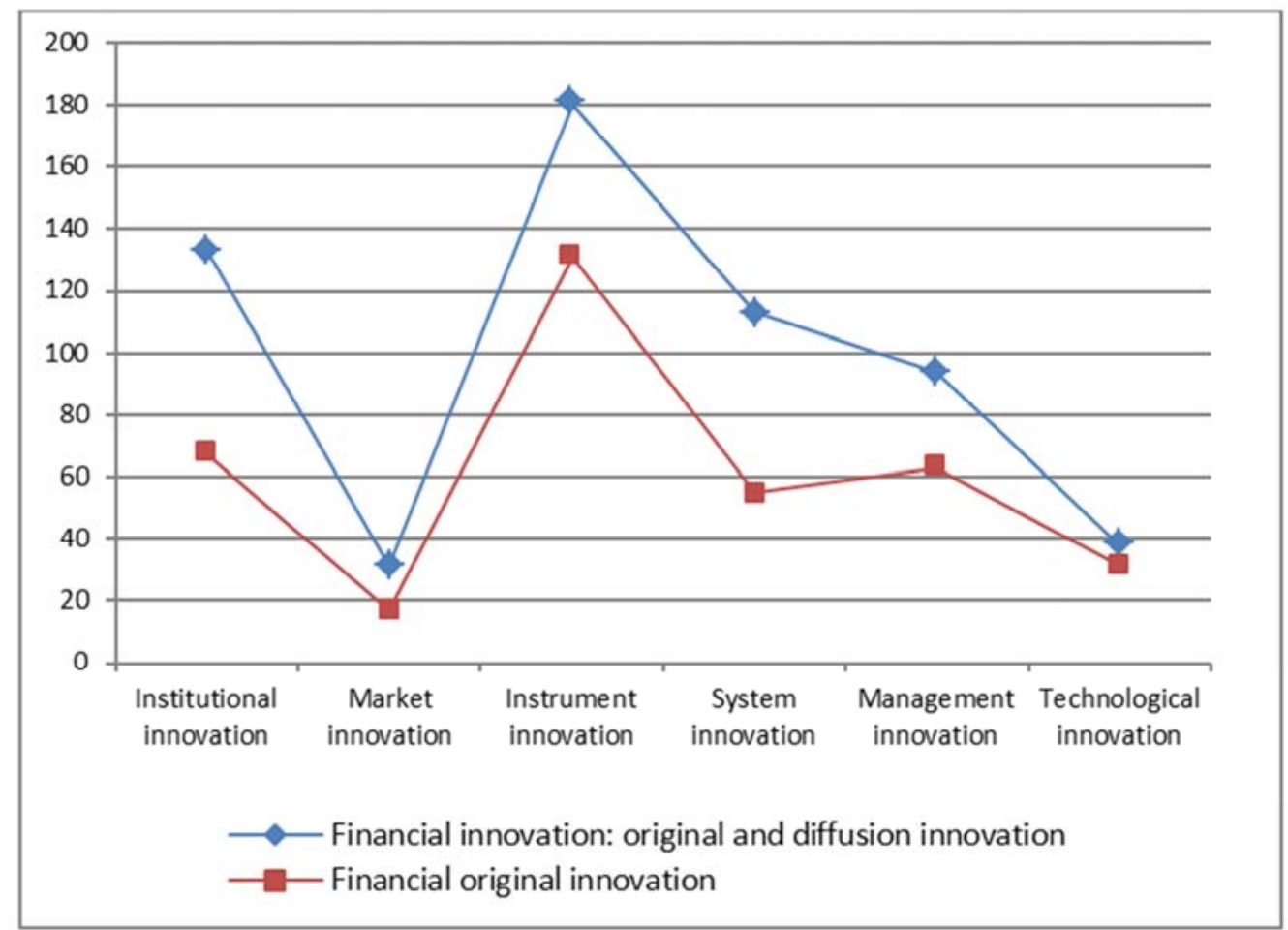

Figure 2. Cumulative number of eventsof six categories of financial innovations in China from 1979 to 2015 (including the cumulative number of original innovation events). 


\subsubsection{Classification of Financial Innovation Events in China}

According to the different attributes of the financial innovation, this paper divides financial innovation events into two types: financial original innovation and financial diffusion innovation. Among them, the original financial innovation refers to innovation events that have appeared in China for the first time since $1979^{\circledR}$. The financial diffusion innovation refers to innovative events that emerge through replication, improvement, or differentiation after the original innovation. In the case of a specific innovation event, the impact and significance of the original innovation is greater than the subsequent diffusion innovation.

According to the components of the financial system, this paper divides the innovation into different categories according to different "forms": (1) institutional innovation, (2) market innovation, (3) instrument innovation, (4) system innovation, (5) management innovation, (6) Technological innovation. Among them, the institutional innovation reflects various new types of financial institutions established or introduced by China since the reform and opening up; The market innovation reflects new types or levels of financial markets established or introduced by China; Theinstrument innovation reflects new financial instruments established or introduced by China; The system innovation reflects the reform of China's financial system to meet the needs of market economy; The management innovation reflects innovations in China's financial regulation, financial regulation, and financial management; The technological innovation reflects innovations in the integration of China's finance and technology, such as the emergence of Internet finance, etc..

\subsubsection{Statistical Analysis of Financial Innovation Events}

From 1979 to 2015, the cumulative number of financial innovation events in China has increased year by year. As of the end of 2015, there were 589 financial innovation events, including 364 financial original innovation events and 225 financial diffusion innovation events ${ }^{2}$. Judging from the trend of the two types of innovation, the proportion of the original innovation in the total innovation tended to decrease, while the proportion of the diffusion innovation tended to increase. As of the end of 2015, the proportion of the original innovation reached $61.8 \%$, while the proportion of the diffusion innovation reached $38.2 \%$ so that the proportion of the diffusion innovation was still lower than the original innovation. In addition, judging from the number of financial innovation events that occurred in the same year, the number of financial innovation events in that year showed an upward trend of fluctuation from 1979 to 2004 . What's more, the number of financial innovation events in the year showed a volatility decline from 2005 to 2015 , reflecting the growing maturity of China's financial system. Figure 1 shows the number of annual events of the financial innovation and the original financial innovation in China.

From 1979 to 2015, the cumulative number of six types of financial innovations in China has gradually increased. By the end of 2015, there have been 133 financial institution innovations (including 67 original institutional innovations), 31 market innovations (17 original market innovations), 180 instrument innovations (131 original instrument innovations), 113 system innovations (55 original system innovations), 94 management innovations (63 original management innovations), and 38 technological innovations (31 original technological innovations). From the trend of the proportion of the original innovation in the six types of innovations, the proportion of the original innovation in most innovations tends to decrease, but the proportion of the original innovations in technological innovation has risen from 1990 to 2015. What's more, it has reached $81.6 \%$ as of the end of 2015 , which reflects the remarkable impetus of scientific and technological progress to the original innovation of financial technology (such as the rapid development of financial technology). Figure 2 reflects the cumulative number of events in China's six categories of financial innovations (and their original innovations) from 1979 to 2015. In addition, appendix table 1 presents the number of innovation events of the year in different attributes and different forms of financial innovations.

\subsection{Index Compilation Method for Financial Innovation Structure}

The financial innovation structure itself cannot be directly measured; therefore it is necessary to use the comprehensive evaluation method and the weighted arithmetic mean index method. First of all, the financial innovation structure is decomposed according to the constituent elements so that an index system reflecting the financial innovation structure is constructed. The final level index of the index system can only be directly measured. Then, the weighted arithmetic mean index method is used to sum up the index values step by step to obtain the structural index of financial innovation, which is used to comprehensively evaluate the structural characteristics of China's financial innovation.

\footnotetext{
(1)According to this definition, the financial innovation that has existed abroad but has been introduced into China for the first time belongs to the original financial innovation.

(2)In the process of collating and summarizing financial innovation events, the summary difficulty of diffusion innovation events is more difficult than that of original innovation events. Therefore, the diffusion innovation events, which are only representative and easy to be counted, such as the establishment of many national joint-stock banks, etc..
} 


\subsubsection{Construction of Index System}

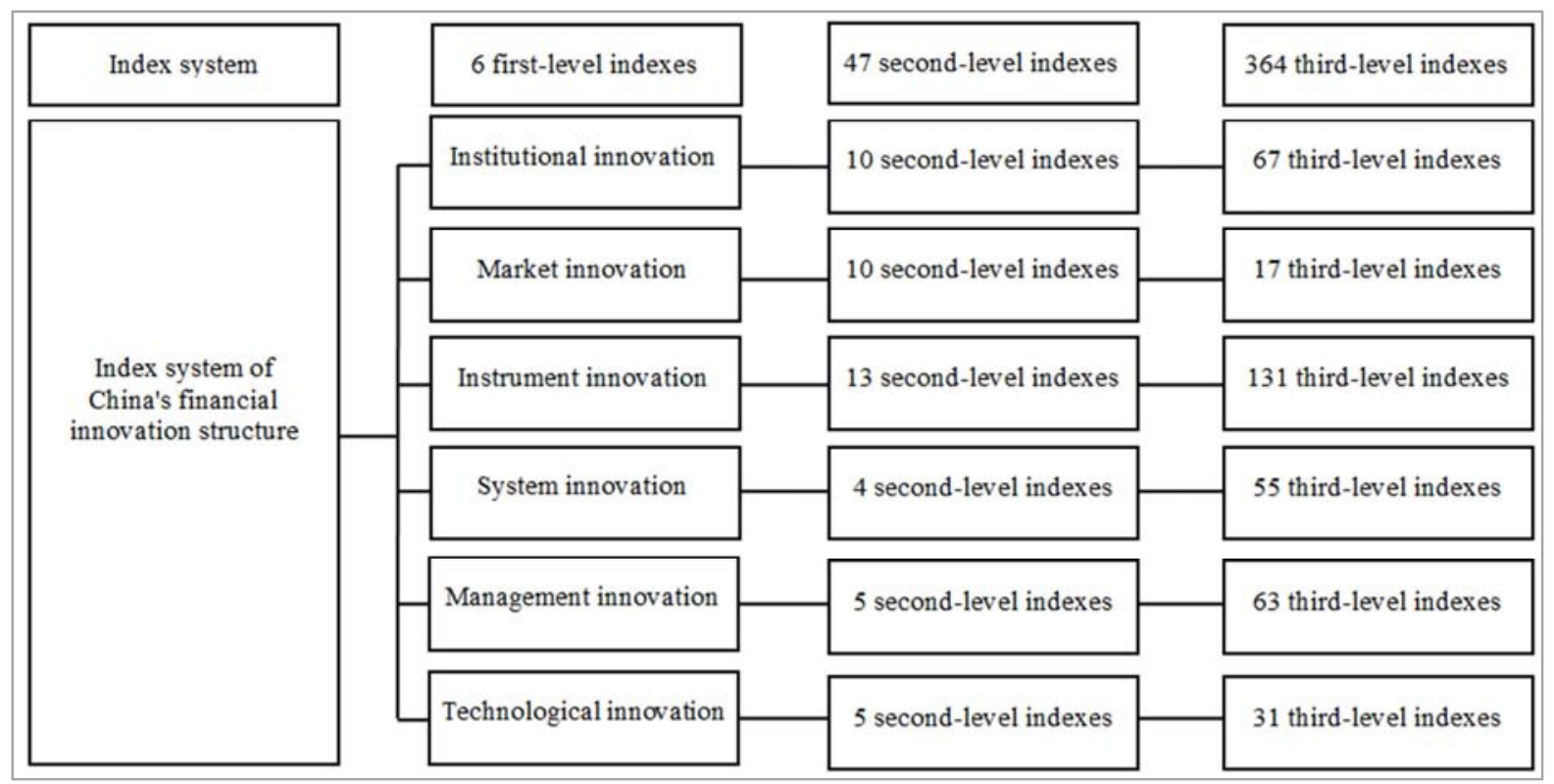

Figure 3. Number of indexes at all levels in the index system of financial innovation structure.

In accordance with the principle of rationality, comprehensiveness, importance and openness, this paper constructs a three-level index system for financial innovation structure. Among them, (1) the first-level index covers various forms of innovation, including institutional innovation, market innovation, instrument innovation, system innovation, management innovation and technological innovation. (2) The second-level indexis the sub-element of the first-level index, embodying the internal composition of the six elements: Among them, $<1>$ the institutional innovation sets up 10 second-level indexes by referring to the Code Specification for Financial Institutions of the People's Bank of China; $<2>$ the market innovation sets up 10 second-level indexes by referring to types of financial markets; $<3>$ the instrument innovation sets up 13 second-level indexes by referring to the Statistical Classification And Coding of Financial Instruments of the People's Bank of China; $<4>$ the system innovation sets4second-level indexes based on financial development and deepening theory; $<5>$ the management innovation sets 5 second-level indexes according to different management subjects; $<6>$ the technological innovation sets up 5 second-level indexes according to different technical application fields. (3) The third-level index is a control index, which can reflect the second-level index in many aspects. In addition, the three-level index has a clear definition and data availability. In view of the characteristics of financial innovation events such as mutation, difficulty in prediction and difficulty in measurement, this paper adopts the "event research method". In the case of one index, a financial innovation event in a certain year is recorded as 1 . In the absence of a financial innovation event in a certain year, it is recorded as $0^{(1)}$. Furthermore, this paper enhances the rationality, comprehensiveness and importance of the index system with the scientific and authoritative summary and classification of financial innovation events. With the emergence of other innovation events in the future, new index will be continuously introduced to ensure the openness of the indicator system. Figure 3 reflects the number of index at all levels of the index system. Figure 4 reflects the names of the first-level and second-level indexes in the index system.

\subsubsection{Index Weight and Assignment}

This paper sets the weight of the index at all levels and the assignment of the original innovation and the diffusion innovation in the third-level index through the expert scoring method, as shown in Table 1. The expert scoring method draws on the classification thought of Kaminsky and Schmukler [9], as well asAbiad and Mody [3], reflectingthat different attributes and forms of innovation events have different importance and influence. In addition, the index of financial innovation structure is obtained by using the weighted arithmetic mean index method to sum up the weights of indexes at all levels from bottom to top according to the index weight and assignment. Furthermore, 6first-level indexes can be used as six sub-indexes reflecting the internal structure of the financial innovation.

\subsection{Index of China's Financial Innovation Structure: 1979-2015}

The structural index of financial innovation in China (see

(1)For example, China established the first village bank in 2007, which belongs to a financial innovation event. As a result, the third-level index "village bank" is set up under the second-level index "banking deposit financial institution", which is recorded as 1 in 2007 and 0 in other years. 
figure 5) and its six sub-indexes (see figure 7) reflect the characteristics and trends of the overall structure and internal structure of the financial innovation respectively.

\subsubsection{The Overall Structural Characteristics and Changing Trends of the Financial Innovation}

(1) The structural index of the financial innovation continues to rise, reflecting the overall structure of the financial innovation is becoming more and more complex. The index rose from 55 in 1979 to 1525.5 in 2015 with an annual growth rate of 9.7 percent.

(2) The index growth slows down. The average annual growth rate of the index from 1979 to 1991 was $17.6 \%$, the average growth rate from 1991 to 2003 was $7.8 \%$, and the average annual growth rate of the index from 2003 to 2015 was $4.1 \%$.

(3) In the process of index growth, the cumulative contribution of the financial diffusion innovation increased from 7.3 percent in 1979 to 30.1 percent in 2015 , but still was lower than that of the original innovation.

(4) The annual increase of the index showed a cyclical change. In 1979-2004, the annual increase of the index increased in a fluctuating trend, and that in 2004-2015 showed a trend of fluctuation and decline. In addition, the five-year moving average of the index increase in the current year presents an inverted "U" shape, reflecting the maturity of the overall structure of the financial innovation, as shown in figure 6 .

(5) During each short period of about five years, the peak years of the index's increase in the year coincided with major conferences such as the year when the third Plenary Session of the CPC Central Committee was held (or one year after the meeting) ${ }^{(1)}$, reflecting the impact of China's major reform policies on the overall structure of the financial innovation.

\subsubsection{Internal Structure Characteristics and Trends of the Financial Innovation}

(1) The six sub-indexes reflecting the internal structure of the financial innovation are rising continuously, reflecting that the internal structure of the financial innovation is becoming more and more complex.

(2) The cumulative contribution of the six types of innovation forms to the financial innovation structure index has been continuously adjusted and gradually formed into three echelons. $<1>$ From a single innovation perspective, the institutional innovation was the most innovative form of cumulative contribution to the financial innovation structure index from 1979 to 1981 and from 2005 to 2015; The market innovation exceeded the institutional innovation in 1982-2004 to become the largest cumulative contributor to innovation in that period and it was ranked third in 2015; The

(1)For example, in 1979, 1984, 1999, 2004, 2009 and 2013. In addition, the peak in 1992 was related to the establishment of a socialist market economic system in China and the overall promotion of financial industry reform in that year. system innovation accelerated in 1992, surpassing the market innovation in 2015 to become the second largest form of innovation in the cumulative contribution; The management innovation emerged in 1986, and gradually surpassed the instrument innovation in 2004, becoming the fourth largest innovation form of the cumulative contribution. $<2>$ From the perspective of echelon distribution, the cumulative contribution of the institutional, system and market innovation to the index of financial innovation structure is in the first echelon, all above 350 points by the end of 2015; That of the management and instrument innovation is in the second echelon, all above 150 points; That of the technological innovation is in the third echelon, around 90 points, as shown in figure 7.

(3) The cumulative contribution ratios of the six types of innovation forms have been adjusted in three stages: $<1>$ From 1979 to 1991, six types of innovation forms appeared successively so that the cumulative contribution ratioswere adjusted and the trend was unknown; <2> Form 1992 to 2004, the cumulative contribution ratios of 6 innovation forms have a tendency to differentiate: the ratioof the institutional, market and instrument innovations has declined, the ratioof the system, management and technological innovation has increased, but the summation of the ratios of the system, management and technological innovation is still low; $<1>$ From 2005 to 2015, the cumulative contribution ratios of the six types of innovation forms tend to be stable: the cumulative contribution ratio of the institutional, market and system innovation accounts for about $24 \%$, and the ratio of the management and instrument innovation is about $11 \%$, as well as the ratio of the technological innovation is about 6\%, as shown in Figure 8.

(4) The cumulative contribution ratios of the six types of innovation to the financial innovation structure index are similar. The coefficient of variation of the cumulative contribution ratios of the six types of innovation decreased from 1.38 in 1979 to 0.49 in 2015.

(5) The frequency of innovation and the distribution of innovation amplitudes of the six types of innovations are different. $<1>$ Institutional, instrument, and system innovations have a higher frequency of innovationwith no innovation years accounting for less than $11 \%$; the distribution of innovation is relatively average and the proportions of the large innovation, moderate innovation, and small innovation are similar. $<2>$ The frequency of innovation in management innovation is moderate, and the years without innovation account for $27 \%$; the distribution of innovation is relatively even, and the proportions of large innovation, moderate innovation and small innovation are similar. $<3>$ The frequency of innovation in market and technological innovation is relatively low, and the years without innovation account for more than $40 \%$; the innovation range is mainly based on the large innovation or the 
moderate innovation in most years, supplemented by

the small innovation in a few years, as shown in Table 2.

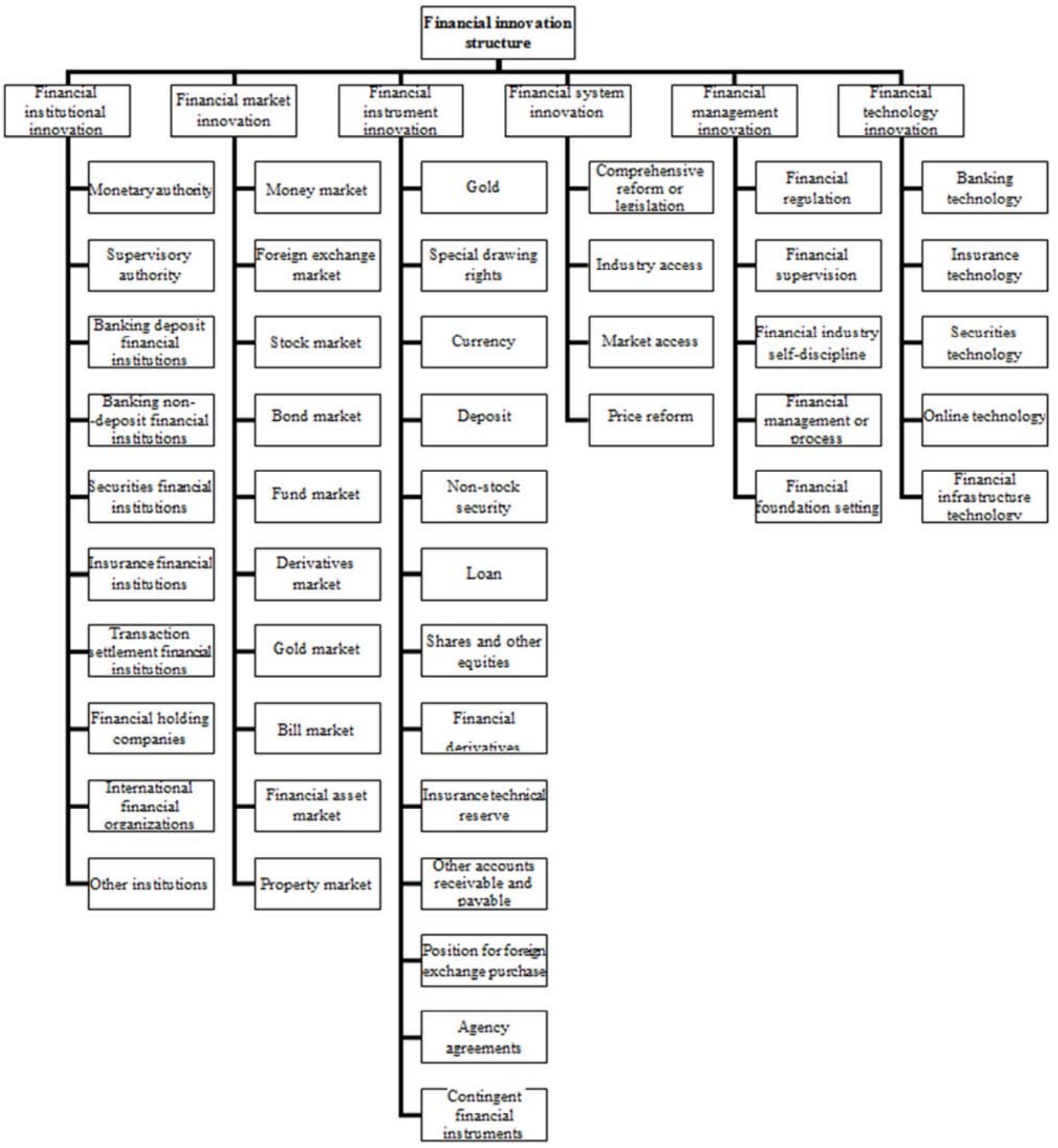

Figure 4. The first-level and second-level indexes of the financial innovation structure index system.

Table 1. Weight setting of indexes at all levels and assignment of two attribute innovation events in the index system of financial innovation structure.

\begin{tabular}{|c|c|c|c|c|c|c|}
\hline $\begin{array}{l}\text { The first-level } \\
\text { index }\end{array}$ & Weight & The second-level index & Weight & $\begin{array}{l}\text { Weight of the } \\
\text { third-level index }\end{array}$ & $\begin{array}{l}\text { Attribute of } \\
\text { innovation event }\end{array}$ & Assignment \\
\hline \multirow{2}{*}{$\begin{array}{l}\text { Financial institution } \\
\text { innovation }\end{array}$} & \multirow[b]{2}{*}{2} & The second-level indexes of 1-9 & 2 & \multirow{5}{*}{1} & Original innovation & 1 \\
\hline & & $\begin{array}{l}\text { The second-level index of } 10 \text { (namely: other } \\
\text { institutions) }\end{array}$ & 1 & & Diffusion innovation & 0.5 \\
\hline \multirow{2}{*}{$\begin{array}{l}\text { Financial market } \\
\text { innovation }\end{array}$} & \multirow[b]{2}{*}{10} & \multirow{2}{*}{$\begin{array}{l}\text { The second-level indexes of 1, 2, 5, 6, 8, 9, } 10 \\
\text { The second-level indexes of 3, 4, } 7 \text { (stocks, } \\
\text { bonds, gold) }\end{array}$} & 2 & & Original innovation & 1 \\
\hline & & & 1 & & Diffusion innovation & 0.5 \\
\hline $\begin{array}{l}\text { Financial instrument } \\
\text { innovation }\end{array}$ & 1 & $\begin{array}{l}\text { The second-level indexes of 1-13 (all } \\
\text { second-level indexes) }\end{array}$ & 1 & & $\begin{array}{l}\text { Original innovation } \\
\text { Diffusion innovation }\end{array}$ & $\begin{array}{l}1 \\
0.5\end{array}$ \\
\hline
\end{tabular}




\begin{tabular}{|c|c|c|c|c|c|c|}
\hline $\begin{array}{l}\text { The first-level } \\
\text { index }\end{array}$ & Weight & The second-level index & Weight & $\begin{array}{l}\text { Weight of the } \\
\text { third-level index }\end{array}$ & $\begin{array}{l}\text { Attribute of } \\
\text { innovation event }\end{array}$ & Assignment \\
\hline \multirow{2}{*}{$\begin{array}{l}\text { Financial system } \\
\text { innovation }\end{array}$} & \multirow[t]{2}{*}{4} & $\begin{array}{l}\text { The second-level index of } 1 \text { (namely, } \\
\text { comprehensive reform or legislation) }\end{array}$ & 2 & & Original innovation & 1 \\
\hline & & The second-level indexes of 2-4 & 1 & & Diffusion innovation & 0.5 \\
\hline \multirow{2}{*}{$\begin{array}{l}\text { Financial } \\
\text { management } \\
\text { innovation }\end{array}$} & \multirow[b]{2}{*}{2} & The second-level indexes of 1-4 & 1 & & Original innovation & 1 \\
\hline & & $\begin{array}{l}\text { The second-level index of } 5 \text { (namely: } \\
\text { financial infrastructure setting) }\end{array}$ & 2 & & Diffusion innovation & 0.5 \\
\hline \multirow{2}{*}{$\begin{array}{l}\text { Financial technology } \\
\text { innovation }\end{array}$} & \multirow[b]{2}{*}{2} & The second-level indexes of 1-4 & 1 & & Original innovation & 1 \\
\hline & & $\begin{array}{l}\text { The second-level index of } 5 \text { (that is: financial } \\
\text { infrastructure technology) }\end{array}$ & 2 & & Diffusion innovation & 0.5 \\
\hline
\end{tabular}

Note 1: In the third column of the table, the second-level index of $\mathrm{n}$ corresponds to the order and name of the second-level index under each first-level in Figure 4

Note 2: The empowerment of different index in the same level index mainly considers the importance and influence of the innovation events represented by the index, and also takes into account the innovation frequency and the number of events. In the index of the same level, the index representing "innovation event has great influence, innovation frequency is low, and innovation event is less" will be given greater weight. For example, the creation of a new financial market is counted as only one innovation event. Only from the number, the number of financial market innovation events is far lower than the number of other forms of innovation events. However, the importance and influence of establishing a new financial market is very great. Therefore, in the first-level index, the weight of financial market innovation is reset to 10 , which is higher than other indexes.

Table 2. The innovation frequency of 6 kinds of financial innovation forms and the innovation range in the current year.

\begin{tabular}{|c|c|c|c|c|c|c|}
\hline Six types of innovation forms & $\begin{array}{l}\text { Institutional } \\
\text { innovation }\end{array}$ & $\begin{array}{l}\text { Market } \\
\text { innovation }\end{array}$ & $\begin{array}{l}\text { Instrument } \\
\text { innovation }\end{array}$ & $\begin{array}{l}\text { System } \\
\text { innovation }\end{array}$ & $\begin{array}{l}\text { Management } \\
\text { innovation }\end{array}$ & $\begin{array}{l}\text { Technologica } \\
\text { I innovation }\end{array}$ \\
\hline Proportion of significant innovation years & $29.7 \%$ & $29.7 \%$ & $24.3 \%$ & $32.4 \%$ & $27.0 \%$ & $27.0 \%$ \\
\hline Proportion of moderate innovation years & $24.3 \%$ & $18.9 \%$ & $43.2 \%$ & $24.3 \%$ & $27.0 \%$ & $24.3 \%$ \\
\hline Proportion of small innovation years & $37.8 \%$ & $8.1 \%$ & $27.0 \%$ & $32.4 \%$ & $18.9 \%$ & $8.1 \%$ \\
\hline Proportion of years without innovation & $8.1 \%$ & $43.2 \%$ & $5.4 \%$ & $10.8 \%$ & $27.0 \%$ & $40.5 \%$ \\
\hline
\end{tabular}

Note: the proportion of significant innovation years refers to the year proportion that the variable quantity of one innovation sub-index is more than $130 \%$ of the mean value of its 37 years in that year; The proportion of moderate innovation years refers to the year proportion that the variable quantity of one innovation sub-index is between $70 \%$ and $130 \%$ of the mean value of its 37 years in that year; The proportion of small innovation years refers to the year proportion that the variable quantity of one innovation sub-index is between $0 \%$ and $70 \%$ of the mean value of its 37 year in that years; The proportion of years without innovation means the year proportion that the variable quantity of one innovation sub-index is 0 in that year.

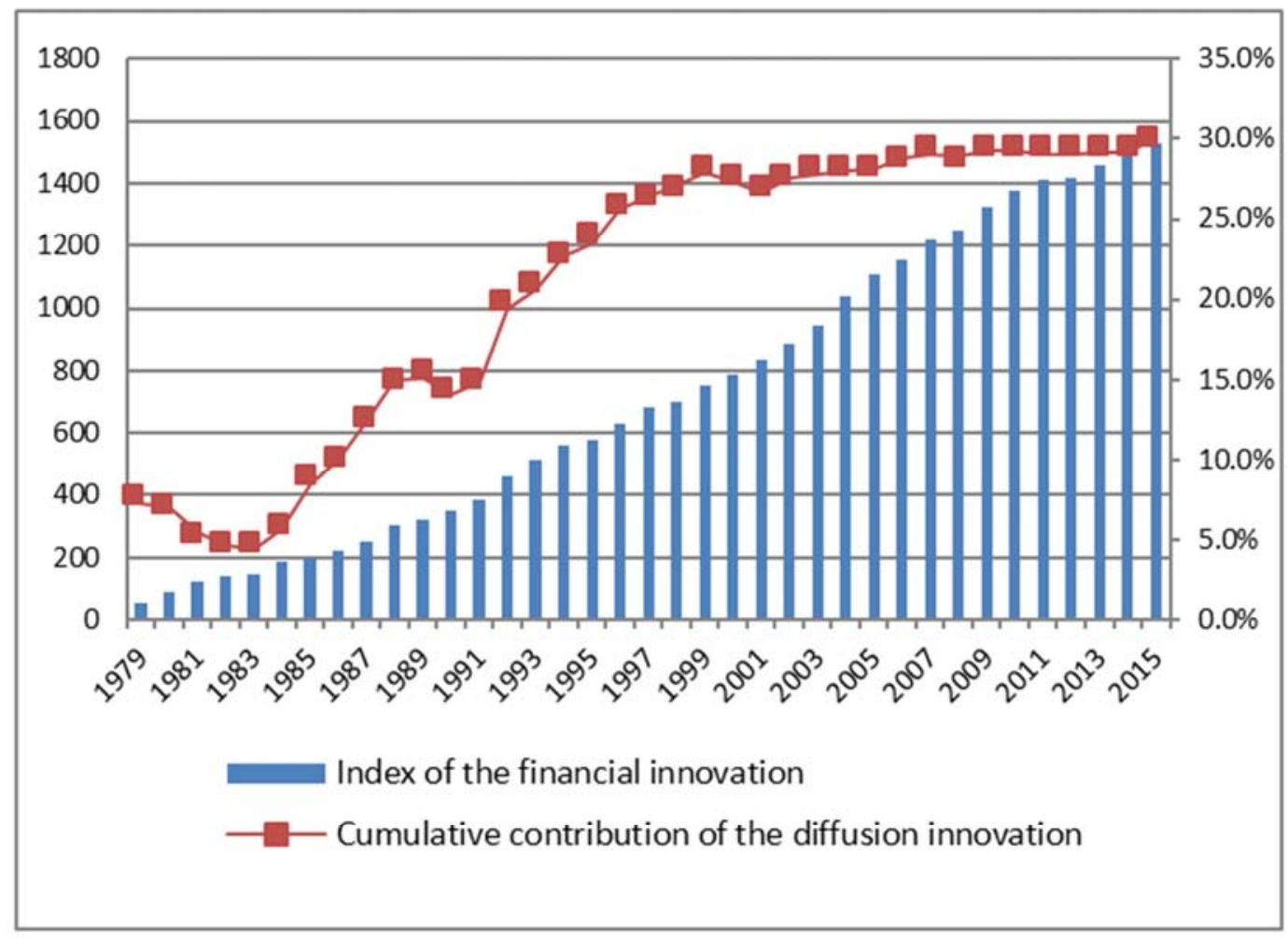

Figure 5. Index of the financial innovation structureand cumulative contribution of the diffusion innovation. 


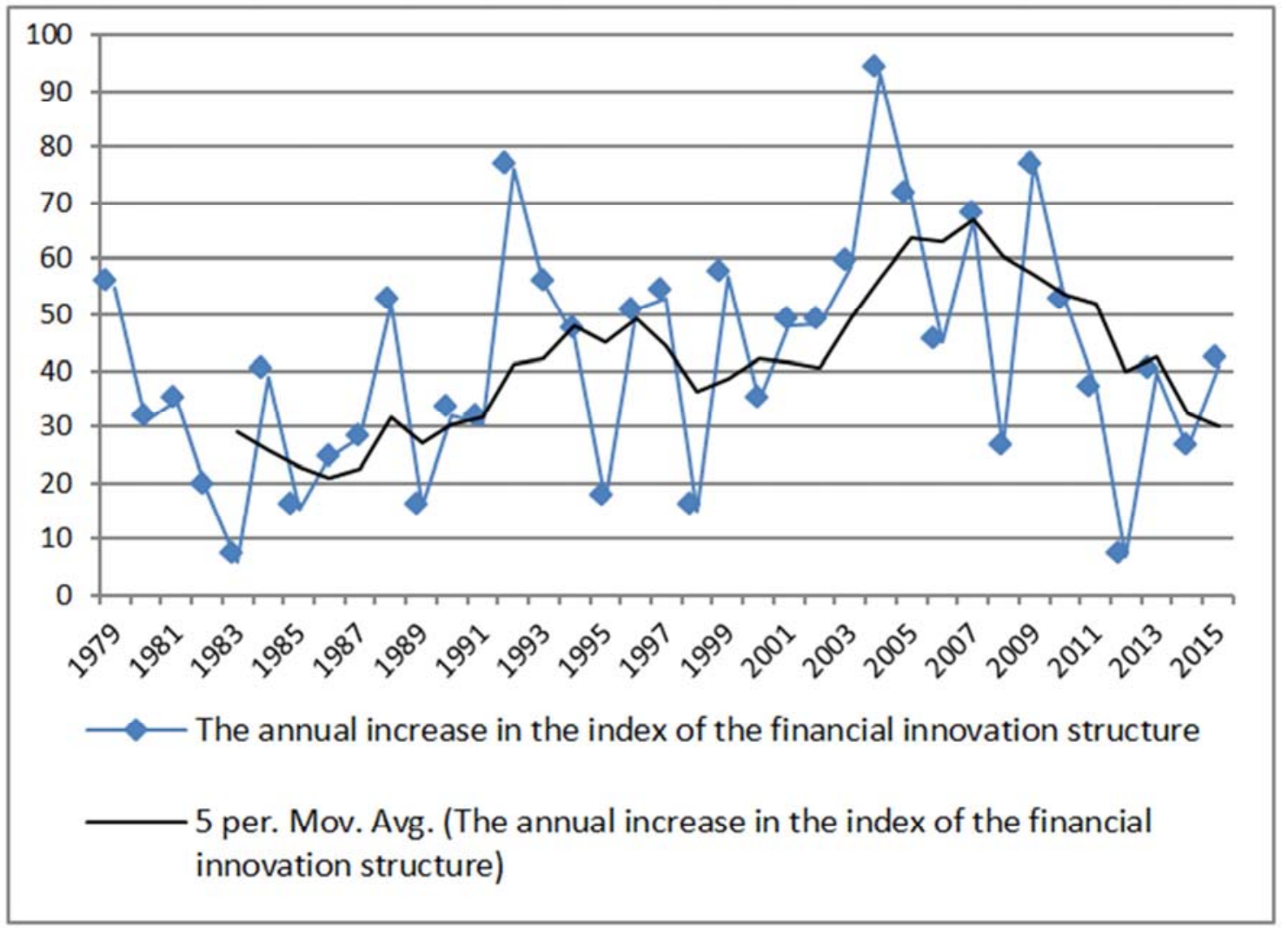

Figure 6. The annual increase in the index of the financial innovation structure and its 5-year moving average line.

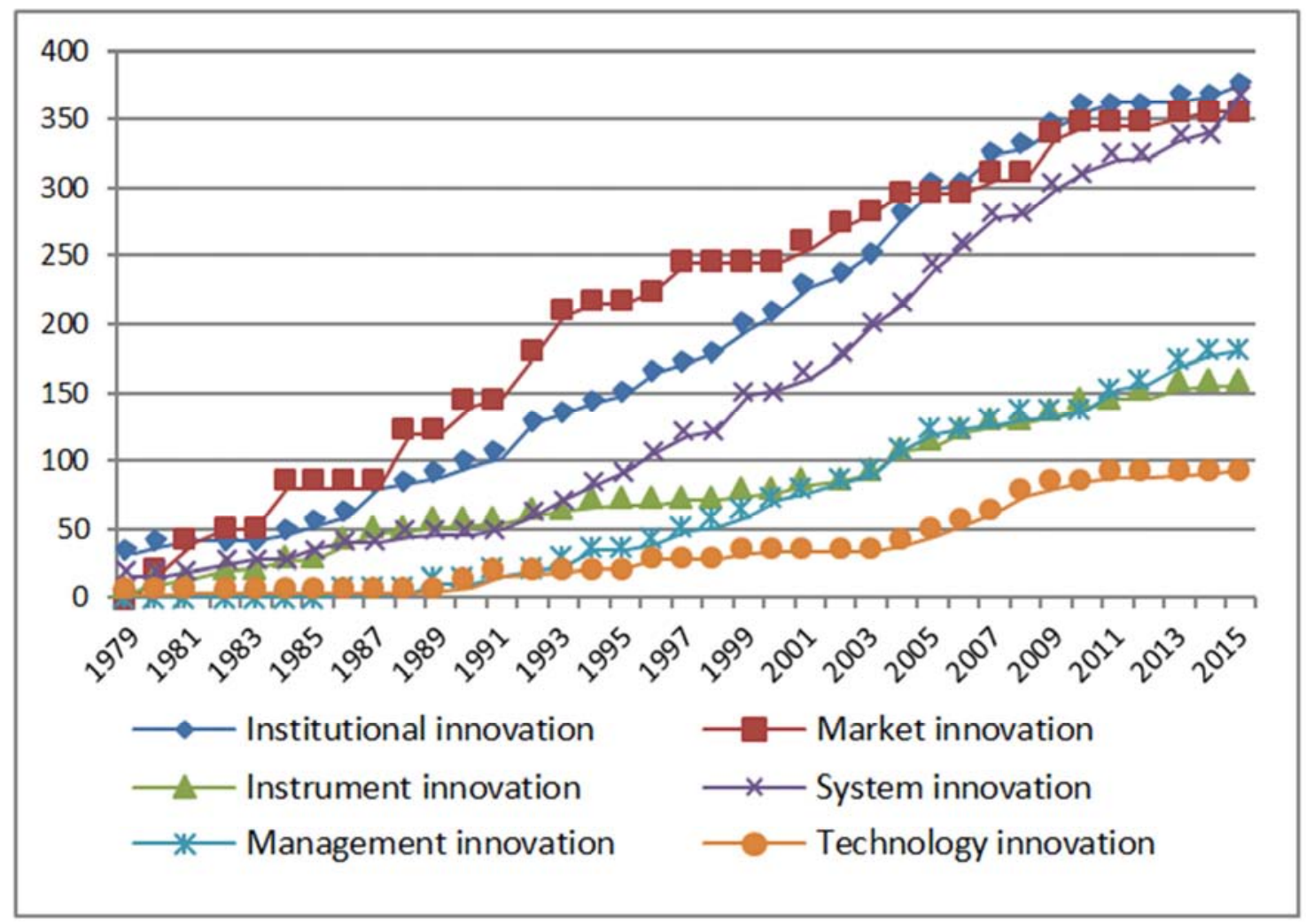

Figure 7. Trends of six sub-indexes reflecting the internal structure of financial innovation. 


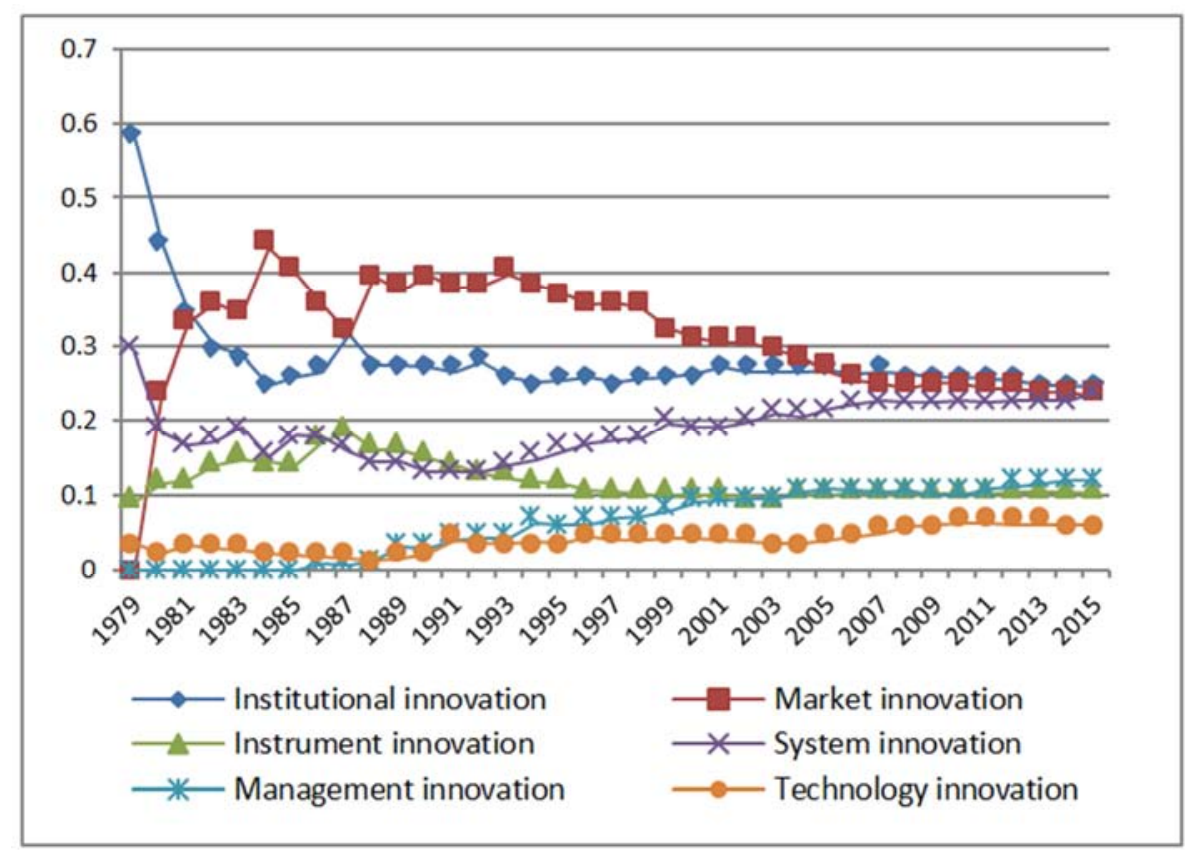

(Three adjustment stage include 1979-1991, 1992-2004, and 2005-2015)

Figure 8. Three adjustment stages of cumulative contributions of six types of innovation forms.

\section{Theoretical Analysis of the Factors Influencing the Change of Financial Innovation Structure}

After measuring the structural change in the financial innovation, this paper further explores why the structure of the financial innovation changed. That is, what factors ${ }^{\mathbb{1}}$ triggered the financial innovation and caused the structural change in innovation. First of all, economists usually explain the occurrence of the financial innovation from a micro, institutional or technical perspective from the academic literature. In addition, this paper identifies five important factors that affect the financial innovation structure based on relevant literature and Chinese experience. Namely, (1) exploration process of the financial innovation, (2) economic shocks, (3) policy factors, (4) opening to the outside world, and (5) scientific and technological progress. What's more, the impact of these factors on the structural change of the financial innovation is not unidirectional.

\subsection{Exploration Process of the Financial Innovation}

The process of exploring the financial innovation will constantly change and shape the financial innovation structure of a country. When the old financial structure cannot meet the requirements of the economic and social development, it will restrict and hinder the economic development. When the expansion of the existing level could not solve the

(1)The factors that trigger the financial innovation are very complex, and different forms of innovation will also affect each other. In order to reduce this complexity, this study is limited to the common factors that affect the change of the financial innovation structure. contradictions in development, only the financial innovation can make qualitative changes, and then change the financial structure to meet the needs of the economic and social development, thus pushing the financial development to a new level. Everything is like that from the early monetary innovation, credit innovation and industrial innovation to the modern new bank innovation, financial institution organization and business innovation, financial market innovation, financial macro management innovation, etc.. In addition, Abiad and Mody [3] (2005) found that the highly depressed economy in the financial system is more inclined to maintain the status according to the experience of 35 economies. However, the tendency to further reforms has increased after the initial institutional innovation. Since China began its economic system reform in 1979, it has gradually broken the financial system of the unification. The financial reform and innovation in 37 years have profoundly changed the structure of the financial innovation. Further more, the successful financial innovation not only promotes the proliferation of the original innovation, but also stimulates the future innovation and exploration, which makes the financial system increasingly market-oriented, international and diversified. All in all, the internal logic of China's financial reform and innovation shows that the process of exploring the financial innovation has a continuous impact on the change in the innovation structure.

\subsection{Economic Shocks}

Economic shocks, such as financial crisis, malignant inflation, and currency deflation, may change the balance of decision-making powers among all countries and lead to the acceleration or reversal of innovation (Krueger [12], 1993; Eduardo and Mauricio [13], 2004). What's more, sometimes 
economic shocks can push back and even promote the financial innovation, while sometimes economic shocks may delay the financial innovation (Wang Shuo et al. [25], 2016). Since the reform and opening up, China has experienced internal disturbances such as excessive inflation and deflation, as well as external shocks such as the Asian financial crisis and the sub-prime crisis in the United States. In the face of economic shocks, decision-making authorities and innovation entities have implemented or suspended the financial innovation depending on the situation. For example, China launched financial market reforms (including the unification of exchange rates) in the face of economic difficulties and high inflation in 1993. In addition, in response to the impact of the sub-prime mortgage crisis, China launched RMB settlement pilot for cross-border trade in 2009 to promote the development of trade between China and its surrounding areas. For another example, the Asian financial crisis has caused the Chinese monetary authority to suspend the capital account convertibility.

\subsection{Policy Factors}

Policy factors reflect the attitude of government toward financial innovation activities, which have a certain impact on the structural change of the financial innovation. Haggard and Webb [14] argued that the new government (the "honeymoon" hypothesis) tended to promote the innovation in the financial system, while La Porta, et al.[15] and Ross Levine, et al. [16] emphasized the importance of the legal system of a country for the financial system innovation. In addition, although there was no clear and effective system in the early days of China's system transition, the encouraging policies of the government have stimulated many financial innovations in China. What's more, although some have been replaced by some negative externality, they have promoted pushed the financial reform to the market-oriented direction. Further more, with the maturity of various conditions, the government has issued a series of policies to support the financial innovation in order to improve the function and efficiency of the financial industry. Generally speaking, the Chinese government has always attached great importance to the top-level design of financial innovation. Therefore, each major conference and reform decision-making will deploy a number of financial innovation tasks. In view of the lessons of the sub-prime crisis, the policy orientation of the Chinese government to promote the financial industry to support the real economy in recent years has also affected the structure of China's financial innovation.

\subsection{Opening to the Outside World}

Opening to the outside world helps to absorb the international innovation achievements and narrow the gap between a country and other active financial innovation countries. Rajan and Zingales [17] believed that the more open the economy, the easier it is to carry out financial market reforms. Ang and Kumar [18] found that innovation results are diffused on the basis of information effect, experience effect and externality effect. Since the reform and opening up, China has implemented a strategy of gradually expanding its openness and has steadily arranged open areas and sequences. In addition, China paid attention to the absorption and improvement of innovation, and formed a batch of innovations that suit domestic conditions in the process of learning from foreign financial innovations. At the same time, the government encouraged local financial institutions to attract investment, such as the shareholding system reform of state-owned banks, which created the form of ownership of mixed ownership based on state-owned capital, foreign capital and private capital, not only innovating the capital structure, but also forming a large number of innovative achievements in many aspects, such as management, product structure and technical means. Further more, with the improvement of China's economic strength and the expansion of opening up to the outside world, Chinese financial institutions have accelerated the pace of international development, opening up a broader space for development in the world, and constantly innovated in financial supervision and corporate governance, gradually reaching the international standard. However, opening up to the outside world will also lead to the transnational spread of financial risks, and may even trigger financial turmoil. Therefore, China is highly vigilant about financial innovation business that is easy to amplify risks, and has done that something can be done but something could not be done.

\subsection{Scientific and Technological Progress}

Since 1965, the information technology revolution based on microelectronics and computers has had a profound impact on the financial industry. Since the beginning of the use of computer processing business in 1974, the integration of finance and technology has continued to deepen, computerize financial services has rapidly spread, and the content of financial technology has been continuously improved. Today, financial technology innovations such as the Internet, Cloud computing, Big data, and Blockchain are emerging one after another. In particular, the rapid rise of Internet finance has become a microcosm of the impact of technological advancement on the structure of the financial innovation. While promoting scientific and technological innovation, scientific and technological progress has also presented new challenges to the orderly development of the financial security, the financial supervision and the regulation of the financial industry.

\section{Empirical Analysis on the Influencing Factors of the Financial Innovation Structure Change}

Based on the structural index of the financial innovation, this paper empirically analyzes the relationship between the overall structure and internal structure of the financial innovation and the above factors.

The structural index of the financial innovation changed from the $F S_{1979}$ in 1979 (the first observation period) to the $F S_{2015}$ in 2015 (the last observation period). In order to 
facilitate the empirical analysis, this paper divides the values of each period of the index by $F S_{2015}$ to obtain the unitized index $F I_{t}$. Among them, the $\frac{F S_{1979}}{F S_{2015}}$ presents the financial innovation structure of 1979 and 1 indicates the financial innovation structure in 2015. The explained variable $\Delta F I_{t}$ in this paper reflects the overall structural change of the financial innovation. $F I_{i t}$ and $\Delta F I_{i t}$ represent respectively 6 innovation structure sub-indexes and their respective changes $(i=1,2, \ldots 6)$. In addition, the basic linear regression model and the mixed cross section model are used to analyze the influence of various factors on the $\Delta F I_{t}$ (the total structural change of innovation) and the $\Delta F I_{i t}$ (the change of internal structure of innovation) respectively in this paper.

\subsection{Model Design and Data Description}

\subsubsection{Reference Model}

As described in the theoretical analysis, the structural change of the financial innovation is influenced by (1) exploration process of the financial innovation, (2) economic shocks, (3) policy factors, (4) opening to the outside world, and (5) scientific and technological progress and so on. First of all, the "exploratory process" of financial innovation is modeled by using the method of Abiad and Mody [3] for reference to set up a simplified dynamic process. The structural change of the financial innovation in $t$ period is determined by the gap between the ideal financial innovation structure $\left(F I_{t}^{*}\right)$ and the financial innovation structure $\left(F I_{t-1}\right)$ in the t-1period. In addition, this dynamic process can be written:

$$
\Delta F I_{t}=\sigma\left(F I_{t}^{*}-F I_{t-1}\right)+\varepsilon_{t}
$$

Among them, the coefficient $\sigma$ indicates the tendency to support the change of the financial innovation structure. The bigger the $\sigma$ is, the greater the tendency to support the change of the financial innovation structure. Assume that $\sigma$ is a function $\sigma=\theta_{1} \cdot F I_{t-1}$ of the financial innovation structure in the $\mathrm{t}$-1period, and infer $\theta_{1}>0$. That is, the welfare improvement was not obvious and the tendency to support the innovation structure change was small at the beginning of the change of the financial innovation structure. In addition, the welfare improvement is obvious and the tendency to support the innovation structure change is great with the maturity of the financial innovation structure. Further more, because $F I_{t}^{*}$ is not observable, this paper firstly assumes the ideal financial innovation structure in the reference model 1. This assumption implies that policy makers believe that structural change in the financial innovation can help improve welfare, and that the 2015 (the last observation period) financial innovation structure is an ideal "achievable" innovation structure compared to previous periods. Therefore, the formula (1) should be re-written as follows:

$$
\Delta F I_{t}=\theta_{1} \cdot F I_{t-1}\left(1-F I_{t-1}\right)+\varepsilon_{t}
$$

The formula (2) means that the innovation tendency $\left(\theta_{1} \cdot F I_{t-1}\right)$ increases, while the innovation space $\left(1-F I_{t-1}\right)$ decreases $^{(1)}$ (within a given period of time) with the structural index $F I_{t}$ of the financial innovation rising. Under the joint action of the two factors, the current increment curve of the innovation structure index will present the inverted "U" shape of rising first and then descending. This also provides a theoretical inference for explaining the inverted "U" shape of the five-year moving average of the innovation structure index in figure 6.

According to theoretical analysis, factors, such as economic shocks $\left(S_{t}\right)$, policy factors $\left(P_{t}\right)$, opening to the outside world $\left(O_{t}\right)$, as well as scientific and technological progress $\left(T_{t}\right)$, will also affect the structure of the financial innovation. The formula (3) is obtained by incorporating the above variables into the model:

$$
\Delta F I_{t}=\theta_{1} \cdot F I_{t-1}\left(1-F I_{t-1}\right)+\theta_{2} \cdot S_{t}+\theta_{3} \cdot P_{t}+\theta_{4} \cdot O_{t}+\theta_{5} \cdot T_{t}+\varepsilon_{t}
$$

As for the factors of economic shock $\left(S_{t}\right)$, this paper selects three mute variables, namely, financial crisis (CRISES $)_{t}$, currency deflation $\left(D E F L_{t}\right)$ and high inflation $\left(H I N F L_{t}\right)$, to test the impact of economic shocks on the innovation structure. With regard to policy factors, this paper selects mute the variable of major conferences and reform decisions $\left(Y E A R_{t}\right)$ (that is, the third Plenary Session of the CPC Central Committee, etc.) to test the influence of policy factors on the structure of the financial innovation. As for opening to the outside world, this paper selects the degree of openness of service trade $\left(O P E N_{t}\right)$ to test the influence of opening to the outside world. At last, with respect to the progress of science and technology, this paper selects the patent authorization quantity ( $P A T E N T_{t}$ ) to test the influence of the progress of science and technology.

\subsubsection{Data Specification}

In the empirical analysis, the explained variables $\Delta F I_{t}$ and $\Delta F I_{i t}$, as well as the explanatory variables that represent the "exploration process" of the financial innovation $F I_{t-1}\left(1-F I_{t-1}\right)$ and $F I_{i, t-1}\left(1-F I_{i, t-1}\right)$ are all based on the calculation of unit structural index and sub-index. Therefore, this will not be further stated.

The four mute variables of financial crisis ${ }^{(2)}\left(\right.$ CRISES $\left._{t}\right)$, currency deflation $\left(D E F L_{t}\right)$, high inflation ${ }^{3}\left(H I N F L_{t}\right)$ and major conferences and reform decisions $\left(Y E A R_{t}\right)$ are 1 in the

(1) For example, the reform of financial marketization is close to completion. For another example, the potential of imitating foreign financial innovation is becoming smaller, gradually entering the original stage of slow innovation rate, etc..

(2) Considering the superposition effect of the international financial crisis and the European debt crisis, and the statement that the Chinese government regards 2012 as the most difficult year of domestic economy after the international financial crisis, this paper also regards 2012 as the year of financial crisis.

(3) In this paper, the year in which CPI is less than $0 \%$ is the year of currency deflation and the year in which CPI is greater than $10 \%$ is the year of high inflation. 
event year and 0 in the rest years. In this paper, the opening degree of service trade $\left(O P E N_{t}\right)$ is represented by "the proportion of China's imports and exports of services in the world in that year ${ }^{(1)}$, and the logarithmic value of "the amount of patent application authorization in that year of China (2)" is used to represent the amount of patent authorization ( $\left.P A T E N T_{t}\right)$. In addition, relevant data comes from Wind information, the World Bank's global financial development database (GFDD) and so on. In order to be line with the structural index of the financial innovation, the time span of all variables is set from 1979 to 2015 .

\subsection{Empirical Results}

\subsubsection{The Empirical Results of the Relationship Between the Overall Structural Change of the Financial Innovation and Its Influencing Factors}

Table 3 (left) reflects the relationship between the overall structural change of the financial innovation and its influencing factors. The column (1) reflects regression results that the "exploration process" of financial innovation $F I_{t-1}\left(1-F I_{t-1}\right)$ affects the the overall structure change of the financial innovation $\Delta F I_{t}$. The coefficient of $F I_{t-1}\left(1-F I_{t-1}\right)$ is positive and significant at the statistical level of $1 \%$, which verifies the theoretical explanation that the exploration process of the financial innovation promotes the change of the financial innovation structure. At the same time, the positive coefficient is also reasonable to infer that the five-year moving average line of the innovation structure index is inverted " $U$ " shape.

The column (2) in Table 3 (left) reflects the regression results after adding "economic shocks" $\left(S_{t}\right)$ to explain variables, namely, the coefficients of financial crisis ( $C R I S E S_{t}$ ), currency deflation ( $\left.D E F L_{t}\right)$, high inflation $\left(H I N F L_{t}\right)$ are all negative. What's more, the coefficient of financial crisis is significant, while the coefficients of high inflation and currency deflation are not significant. This shows that the financial crisis will restrain the structural change of the financial innovation. Therefore, in order to prevent market confidence from collapsing in times of financial crisis, policy makers may impose stricter regulation on financial innovation activities.

On the basis of retaining the "exploratory process" of the financial innovation and the mute variables of the financial

(1)This index refers to the proportion of China's imports and exports in services to the total world trades in services every year. In addition, the index comes from China's Ministry of Commerce. The selection of this index not only considers that the financial industry belongs to the service industry, but also that it can reflect the trend of China's opening wider to the outside world. The traditional indexes, such as "the proportion of import and export to GDP", have ushered in the turning point and could not better reflect the trend of China's continuous expansion and opening up.

(2) The index refers to the number of exclusive rights granted by the Patent Office of China to inventors and designers in accordance with the law each year, including inventions, utility models and designs. The index, derived from the National Bureau of Statistics, reflects the technological and design results of China's own intellectual property rights. In addition, only the number of patent applications in China from 1985 to 2015 is provided in Wind Information and this paper uses 1985 data to represent the data from 1979 to 1984 to supplement. crisis, three explanatory variables, namely, mute variable of major conferences and reform decisions $\left(Y E A R_{t}\right)$, openness of trade in services $\left(O P E N_{t}\right)$ and patent authorization amount $\left(P A T E N T_{t}\right)$, are added. In addition, the column (3) in Table 3 (left) shows: The coefficient of major conferences and reform decisions is positive and significant, indicating that major reform decisions (policy factors) are the factors that promote the change of the financial innovation structure. The coefficient of openness of trade in services is positive and significant, which indicates that opening to the outside world is the factor to promote the change of the financial innovation structure, which may be related to the diffusion and dissemination of international financial innovation under the open conditions. Further more, the coefficient of patent authorization amount is positive and significant, which reflects the development of science and technology to promote the change of the financial innovation structure. In addition, the coefficient of financial crisis increases significantly after adding three new variables.

\subsubsection{The Empirical Results of the Relationship Between the Change of Internal Structure and the Influencing Factors of Financial Innovation}

According to the formula (4), this paper establishes a model to analyze the relationship between the internal structure change of financial innovation and the influencing factors.

$$
\Delta F I_{i, t}=\theta_{i, 1} \cdot F I_{i, t-1}\left(1-F I_{i, t-1}\right)+\theta_{2} \cdot S_{t}+\theta_{3} \cdot P_{t}+\theta_{4} \cdot O_{t}+\theta_{5} \cdot T_{t}+\varepsilon_{t}
$$

After the Hausman test and F (or LR) test, it is found that there is no significant difference in time and cross-section between individuals. In order to obtain higher estimation efficiency, a mixed cross-section model is established in this paper. Besides, the regression results are shown in Table 3 (right).

In the column (4) of Table 3 (right), shows the regression results that the "exploration process" of financial innovation $F I_{t-1}\left(1-F I_{t-1}\right)$ affects the overall structure change of the financial innovation $\Delta F I_{t}$. The coefficients of $F I_{t-1}\left(1-F I_{t-1}\right)$ are all positive and significant at the statistical level of $1 \%$, which verifies the "exploring process" of six kinds of financial innovation forms can promote the structural change of their own innovation. In addition, this relationship is consistent with the relationship between the "exploration process" of the financial innovation and the overall structural change of innovation.

The column (5) in Table 3 (left) reflects the regression results after adding "economic shocks" $\left(S_{t}\right)$ to explain variables, namely, the coefficients of financial crisis $\left(C R I S E S_{t}\right)$, currency deflation $\left(D E F L_{t}\right)$, high inflation $\left(H I N F L_{t}\right)$ are all negative. The coefficient of financial crisis is significant, while the coefficients of high inflation and currency deflation are not significant. This indicates that the financial crisis will restrain the structural change of the six types of financial innovation, which is consistent with the direction of the impact of the crisis on the overall structural change. 
On the basis of retaining the above explanatory variables, the following three explanatory variables will be added continuously: major conferences and reform decisions $\left(Y E A R_{t}\right)$, openness of trade in services $\left(O P E N_{t}\right)$ and patent authorization amount ( $P A T E N T_{t}$ ). In addition, the column (6) in Table 3 (right) reflects the regression results. The coefficients of the three new explanatory variables are all positive and significant, which indicates that the major reform decisions, opening to the outside world and the progress of science and technology can promote the structural change of the six kinds of financial innovation forms. In addition, the coefficient of the financial crisis increased significantly after the addition of new variables.

Table 3. The relationship between the change of the overall and internal structure and the influence factors of financial innovation: structural index and its six sub-indexes based on the financial innovation.

\begin{tabular}{|c|c|c|c|c|c|c|c|}
\hline \multirow[t]{2}{*}{$\Delta F I_{t}$} & \multicolumn{3}{|c|}{ Structural Index of Financial Innovation } & \multirow{2}{*}{$\Delta F I_{i, t}$} & \multicolumn{3}{|c|}{ Structural Sub-index of Financial Innovation } \\
\hline & (1) & (2) & (3) & & (4) & (5) & (6) \\
\hline \multirow[t]{2}{*}{$F I_{t-1}\left(1-F I_{t-1}\right)$} & 0.1535 & 0.1710 & 0.0877 & \multirow[t]{2}{*}{$F I_{i, t-1}\left(1-F I_{i, t-1}\right)$} & 0.1670 & 0.1850 & 0.1106 \\
\hline & $(10.8817)^{* * *}$ & $(9.5681)^{* * *}$ & $(6.0027)^{* * *}$ & & $(15.7419) * * *$ & $(14.1439) * * *$ & $(6.2225) * * *$ \\
\hline CRISES $_{t}$ & & $\begin{array}{l}-0.0138 \\
(-1.7749)^{*}\end{array}$ & $\begin{array}{l}-0.0170 \\
(-3.2116)^{* * *}\end{array}$ & CRISES $_{t}$ & & $\begin{array}{l}-0.0099 \\
(-1.7677) *\end{array}$ & $\begin{array}{l}-0.0126 \\
(-2.3367) * *\end{array}$ \\
\hline$H I N F L_{t}$ & & $\begin{array}{l}-0.0085 \\
(-1.1527)\end{array}$ & & $H I N F L_{t}$ & & $\begin{array}{l}-0.0082 \\
(-1.5837)\end{array}$ & $\begin{array}{l}-0.0021 \\
(-0.3841)\end{array}$ \\
\hline \multirow{2}{*}{$D E F L_{t}$} & & -0.0024 & & \multirow{2}{*}{$D E F L_{t}$} & & -0.0063 & -0.0108 \\
\hline & & $(-0.2864)$ & & & & $(-1.0656)$ & $(-1.8989)^{*}$ \\
\hline$Y E A R_{t}$ & & & $\begin{array}{l}0.0117 \\
(3.1949) * * *\end{array}$ & $Y E A R_{t}$ & & & $\begin{array}{l}0.0124 \\
(3.2369)^{* * *}\end{array}$ \\
\hline$O P E N_{t}$ & & & 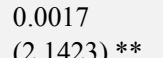 & $O P E N_{t}$ & & & $\begin{array}{l}0.0019 \\
(24304) * *\end{array}$ \\
\hline PATENT $_{t}$ & & & $\begin{array}{l}0.0025 \\
(3.8668) * * *\end{array}$ & $P_{A T E N T}$ & & & $\begin{array}{l}0.0021 \\
(2.8986) * * *\end{array}$ \\
\hline \multirow{2}{*}{ AdjustedR ${ }^{2}$} & \multirow{2}{*}{-0.2038} & \multirow{2}{*}{-0.1673} & \multirow{2}{*}{0.4827} & AdjustedR ${ }^{2}$ & -0.0313 & 0.0582 & 0.1887 \\
\hline & & & & DW statistical quantity & 1.6079 & 1.5762 & 1.7575 \\
\hline \multirow{2}{*}{$\begin{array}{l}\text { DW statistical } \\
\text { quantity }\end{array}$} & \multirow{2}{*}{1.3275} & \multirow{2}{*}{1.1235} & \multirow{2}{*}{1.8158} & Pool observed quantity & 222 & 222 & 222 \\
\hline & & & & Cross-sections & 6 & 6 & 6 \\
\hline \multirow{2}{*}{ Observed quantity } & \multirow{2}{*}{37} & \multirow{2}{*}{37} & \multirow{2}{*}{37} & Hausman test (P value) & 0.3202 & 1 & - \\
\hline & & & & $\mathrm{F}$ test (P value) & 0.9631 & 0.9358 & 0.9291 \\
\hline
\end{tabular}

Note: the explained variable on the left side of this table is the change of the structural index of the unit financial innovation $\Delta F I_{\mathrm{t}}$, and the explained variable on the right side is the change of the structural sub-index of the unit financial innovation $\Delta F I_{i, \mathrm{t}}$. T statistics are in parentheses. $* * *$ indicates they are significant at 1 percent level. **indicates they are significant at 5 percent level. At last, *indicates they are significant at 10 percent level.

Table 4. The relationship between the change of the overall and internal structure and the influence factors of financial innovation under the new model setting.

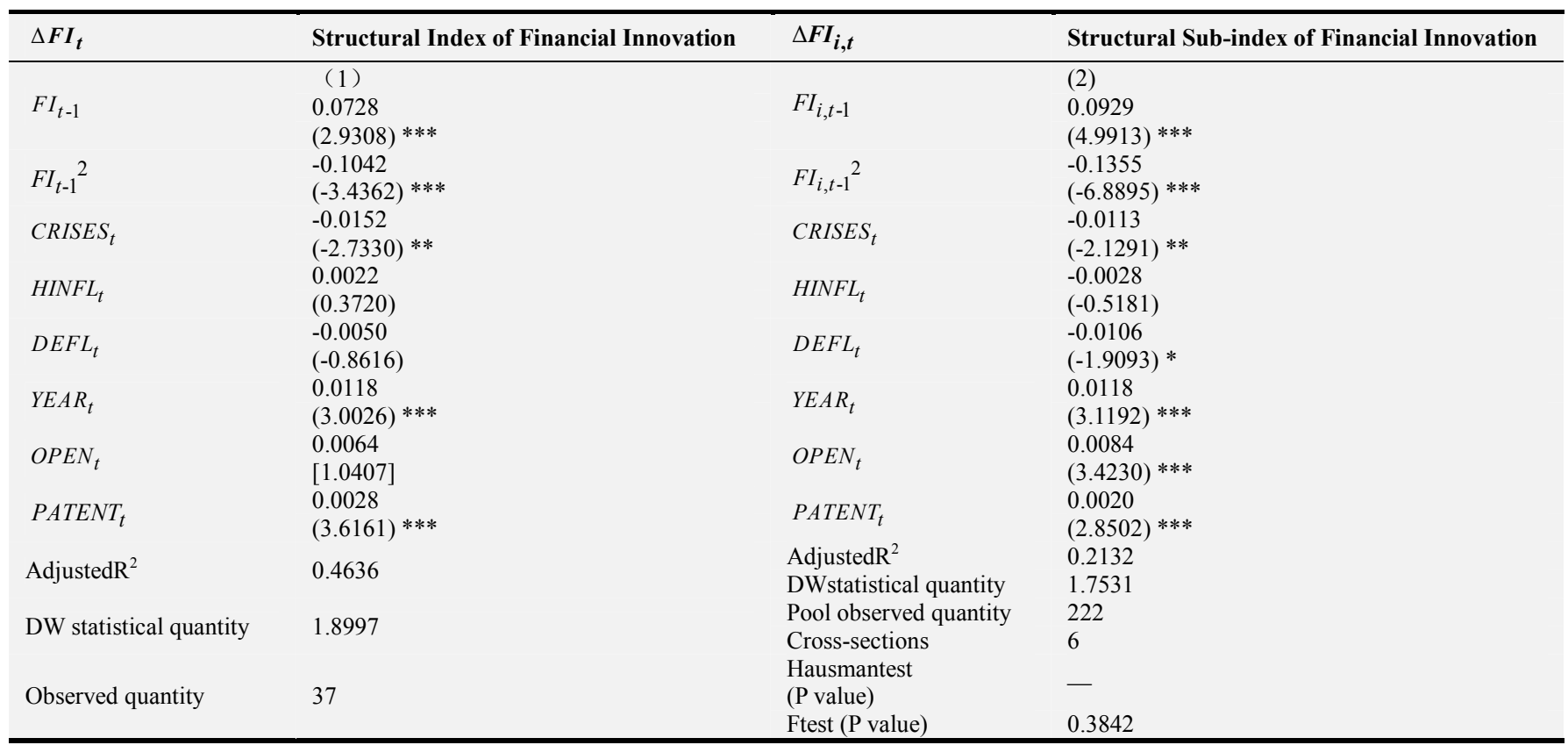

Note: T statistics are in parentheses. $* * *$ indicates they are significant at 1 percent level. **indicates they are significant at 5 percent level. At last, $*$ indicates they are significant at 10 percent level. The P value of Hausman test is "-" because the number of Cross-sections is smaller than the number of explanatory variables so that the random effect variable intercept model could not be established. Therefore, the Hausman test cannot be carried out. 


\subsection{Model Setting Changes and New Empirical Results}

In designing the reference model, this paper have assumed that the ideal financial innovation structure $\left(F I_{t}^{*}\right)$ is 1 , and that the tendency to support the change of the financial innovation structure is the function of the financial innovation structure of the $\mathrm{t}-1$ period. This section will relax these two assumptions to build a more general model.

First of all, the ideal financial innovation structure is no longer equal to $1^{(1)}$, but is equal to a constantc greater than zero, of which $c=\frac{\theta_{1}}{-\theta_{2}}$. In this case, the coefficients of the two must no longer be equal. Therefore, formulas (3) and (4) become formulas (5) and (6) respectively under the new configuration:

$$
\begin{gathered}
\Delta F I_{t}=\theta_{1} \cdot F I_{t-1}+\theta_{2} \cdot F I_{t-1}{ }^{2}+\theta_{3} \cdot S_{t}+\theta_{4} \cdot P_{t}+\theta_{5} \cdot O_{t}+\theta_{6} \cdot T_{t}+\varepsilon_{t} \\
\Delta F I_{i, t}=\theta_{1} \cdot F I_{i, t-1}+\theta_{2} \cdot F I_{i, t-1}{ }^{2}+\theta_{3} \cdot S_{t}+\theta_{4} \cdot P_{t}+\theta_{5} \cdot O_{t}+\theta_{6} \cdot T_{t}+\varepsilon_{t}(6)
\end{gathered}
$$

In this paper, we infer that $\theta_{1}$ is the positive number and $\theta_{2}$ is the negative number. What's more, testing whether or not $\theta_{1}$ is equal to $-\theta_{2}$ is equivalent to testing whether the previous hypothesis that $F I_{t}^{*}$ equals 1 is true. The regression results of formula (5) and formula (6) are presented on the left and right sides of Table 4 respectively. Among them, the column (1) reflects the effects of various factors on the overall structural changeof the financial innovation, and the column (2) reflects the effects on the internal structural change. The regression results are in accordance with the inference, that is, the $\theta_{1}$ is the positive number and the $\theta_{2}$ is the negative number At the same time, the $\theta_{1}$ is less than the $-\theta_{2}$, that is, the ideal financial innovation structure $c=\frac{\theta_{1}}{-\theta_{2}}$ is a positive number less than 1 , indicating that the previous assumption of $c=1$ is too high. Logically, the value of $\mathrm{C}$ may be related to the stage of the financial innovation. According to the explanation of Abiad and Mody [3], as well as Zhou Xiaochuan [26], the lack of clear and effective rules in countries in the early stages of transition will limit the country's ability to carry out far-reaching financial innovation rapidly. Therefore, the ideal financial innovation structure may be set at a lower level in a long period of time.

Other empirical conclusions have not changed substantially due to changes in model settings. What's more, the current increase curve of the structural index is still inverted "U" type. In addition, the negative impact of the financial crisis on changes in the innovation structure and the positive impact of major reform decisions and scientific and technological progress are still significant, whilethe effect of

(1) 1 represents the financial innovation structure of the last observation period (2015). high inflation and currency deflation have not been significant. The one exception is that the coefficient of openness of service trade is no longer significant in the empirical analysis of the influencing factors of the overall structural change of financial innovation, but the coefficient of the variable is still significant in the analysis of the influencing factors of internal structural changes.

\subsection{Robustness Test and Prospect}

For the sake of robustness, this paper conducts several robustness tests. Above of all, to test the impact of international factors on the changes in China's financial innovation structure without changing the explanatory variables, add the international interest rate level ${ }^{(2)}$ to the explanatory variables. At last, the regression results show that the explanatory variable is not significant. Secondly, in order to examine the impact of domestic factors on changes in financial innovation structure, join some variables, such as China's GDP per capita, the interest rate levels (6 - month fixed deposit interest rate ${ }^{(3)}$ ), the proportion the value added in the financial industry accounts for GDP and the financing structure (the proportion the indirect financing accounts for the total financing). At last, the regression results show that these explanatory variables are all not significant. Thirdly, in order to continue the analysis of formula (5) and formula (6) and further investigate whether the idealfinancial innovation structure (that is, c) will change with economic development (such as the change of GDP per capita) or with the change of time, the model setting and sample time span are set up in this paper. However, the regression results are not significant.

Given that the $\mathrm{R}$ side of the regression results is small, other explanatory variables that are not part of the model need to continue to be studied (such as the variables behind the existing influencing factors, etc.). At the same time, whether the structural change of financial innovation and its influencing factors can help explain the change of innovation structure in non-financial sector also needs to be verified. In addition, the relationship between various forms of innovation within the financial innovation structure and the impact of structural changes in financial innovation on economic development are yet to be explored.

\section{Main Conclusions and Policy Recommendations}

The structural index of the financial innovation constructed in this paper reflects that the overall structure of China's financial innovation has become increasingly complex since the reform and opening up, and the contribution of six types of innovations to the change in the innovation structure has become more consistent and stable. Since the influence of

(2)This variable is represented by the one-year federal funds rate in the United States, based on the setting of Abiad and Mody (2005).

(3) The annual value of the interest rate is based on a time weighted average of nominal interest rates. 
various factors on the structural change of the financial innovation is not in the same direction, the continuous exploration and tolerance of financial innovation activities in a country has become an important driving force for maintaining the structural change of the financial innovation. The main conclusions of this paper are as follows:

The structural index of the financial innovation reflects the increasing complexity of the overall structure of China's financial innovation, the slowdown in the structural change, and the increase in the proportion of the diffusion innovation. The index of the financial innovation structure increased volatility from 1979 to 2004 and fluctuated from 2004 to 2015. In addition, under the combined effect of increased innovation tendency and reduced (in a certain stage) innovation space, the curve of the annual increase of the innovation structure index is inverted U-shaped.

The six sub-indexes of the financial innovation structure show that the cumulative contribution of various innovation forms to the overall structural change of the financial innovation is more convergent and stable. After the turbulent adjustments of 1979-1991 and the trend changes of 1992-2004, the cumulative contribution of institutional, market and system innovations was around $24 \%$ in the 11 years from 2005 to 2015 , that of management and instrument innovations was around $11 \%$, and that of technological innovation was around $6 \%$.

The empirical analysis of the influencing factors of the financial innovation structure shows that the exploration process of the financial innovation is the long-term driving force to promote the structural change of China's financial innovation. At the same time, major reform decisions, opening to the outside world, and scientific and technological progress have contributed to the change of China's financial innovation structure, and the financial crisis has a restraining effect on the innovation structure change. What's more, the above conclusions are basically consistent with domestic and foreign theoretical and empirical evidence.

The policy implication of this paper is that China needs to grasp the inherent law of the financial innovation structure change in the face of the increasingly complex and slow-changing financial innovation structure. In addition, the gradual completion of China's financial marketization reform or the narrowing of foreign financial innovation imitation space does not mean the end of the financial innovation structure change. On the contrary, China needs to deepen reforms to create an environment that is more suitable for endogenous financial innovation and foster more financial original innovations that "the speed of innovation is slower, but the practical significance is greater" with the maturity of the financial structure.

With the gradual completion of China's financial marketization reform, the proportion of innovations in financial institutions, markets and instruments is slowly declining, while the proportion of system, management and technological innovations is gradually increasing. However, the total proportion of the latter three innovations is still low (It was $41.95 \%$ at the end of 2015), and the potential is large. Therefore, according to the characteristics of innovation frequency and range of different innovation forms, China needs to adhere to the innovative purpose of improving financial functions and efficiency, steadily promote institutional and management innovations, accelerate the implementation of financial technology innovation, and continuously explore new financial innovation potential.

The structural change of financial innovation is inseparable from the unremitting exploration of the financial innovation. Successful early exploration will enable the financial innovation to enter the track of endogenous development, and thus achieve the sustainability of the financial innovation. In addition, considering the influence of other factors on the structural change of the financial innovation may change from time to time, it is also necessary to pay attention to the selection of the timing and window period of the financial innovation. That is, decisively advance when there is an innovation window, while wait for opportunities when there is no innovation window in order to prevent the excessive adjustment or suppression of the financial innovation structure.

\section{Acknowledgements}

We appreciate the financial support of (1) Central University of Finance and Economics' major scientific research nurturing projects "Research on structural change in financial development" (14ZZD004), (2) Tianjin Philosophy and Social Sciences Research Program "Short term effects of supply side structural reform" (TJYJ18-005), (3) the National Social Science Foundation's major project (17ZDA100), (4) Tianjin Philosophy and Social Sciences Research Program "Research on Tianjin Financial Supply Side Reform" (TJYY16-012).

\section{Appendix}

Table A1. The number of financial innovation events and original financial innovation events in 1979-2015.

\begin{tabular}{|c|c|c|c|c|c|c|c|c|c|c|c|c|c|c|c|c|c|c|}
\hline \multirow{2}{*}{$\begin{array}{l}\text { Year } \\
\text { Innovation attribute }\end{array}$} & \multicolumn{2}{|c|}{1979} & \multicolumn{2}{|c|}{1980} & \multicolumn{2}{|c|}{1981} & \multicolumn{2}{|c|}{1982} & \multicolumn{2}{|c|}{1983} & \multicolumn{2}{|c|}{1984} & \multicolumn{2}{|c|}{1985} & \multicolumn{2}{|c|}{1986} & \multicolumn{2}{|c|}{1987} \\
\hline & $\mathbf{A}$ & B & $\mathbf{A}$ & B & $\mathbf{A}$ & B & $\mathbf{A}$ & B & $\mathbf{A}$ & B & $\mathbf{A}$ & B & $\mathbf{A}$ & B & $\mathbf{A}$ & B & $\mathbf{A}$ & B \\
\hline Financial innovation & 18 & 16 & 8 & 7 & 9 & 8 & 7 & 7 & 3 & 3 & 9 & 7 & 6 & 3 & 17 & 12 & 18 & 9 \\
\hline Institutional innovation & 9 & 7 & 2 & 1 & 1 & 1 & 0 & 0 & 0 & 0 & 2 & 0 & 2 & 1 & 3 & 1 & 7 & 4 \\
\hline Marketinnovation & 0 & 0 & 1 & 1 & 1 & 1 & 1 & 1 & 0 & 0 & 2 & 2 & 0 & 0 & 0 & 0 & 0 & 0 \\
\hline Instrument innovation & 5 & 5 & 5 & 5 & 5 & 4 & 5 & 5 & 2 & 2 & 5 & 5 & 2 & 1 & 12 & 9 & 11 & 5 \\
\hline Systeminnovation & 3 & 3 & 0 & 0 & 1 & 1 & 1 & 1 & 1 & 1 & 0 & 0 & 2 & 1 & 1 & 1 & 0 & 0 \\
\hline Management innovation & 0 & 0 & 0 & 0 & 0 & 0 & 0 & 0 & 0 & 0 & 0 & 0 & 0 & 0 & 1 & 1 & 0 & 0 \\
\hline
\end{tabular}


Table A1. Continued.

\begin{tabular}{|c|c|c|c|c|c|c|c|c|c|c|c|c|c|c|c|c|c|c|}
\hline \multirow{2}{*}{$\begin{array}{l}\text { Year } \\
\text { Innovation attribute }\end{array}$} & \multicolumn{2}{|c|}{1988} & \multicolumn{2}{|c|}{1989} & \multicolumn{2}{|c|}{1990} & \multicolumn{2}{|c|}{1991} & \multicolumn{2}{|c|}{1992} & \multicolumn{2}{|c|}{1993} & \multicolumn{2}{|c|}{1994} & \multicolumn{2}{|c|}{1995} & \multicolumn{2}{|c|}{1996} \\
\hline & $\mathbf{A}$ & B & $\mathbf{A}$ & B & $\mathbf{A}$ & B & $\mathbf{A}$ & B & $\mathbf{A}$ & B & $\mathbf{A}$ & B & $\mathbf{A}$ & B & $\mathbf{A}$ & B & $\mathbf{A}$ & B \\
\hline Financial innovation & 9 & 6 & 9 & 7 & 7 & 6 & 10 & 7 & 24 & 11 & 14 & 9 & 18 & 12 & 7 & 2 & 17 & 9 \\
\hline Institutional innovation & 2 & 0 & 1 & 1 & 2 & 2 & 2 & 1 & 10 & 3 & 2 & 1 & 3 & 1 & 2 & 1 & 5 & 3 \\
\hline Marketinnovation & 3 & 2 & 0 & 0 & 2 & 2 & 1 & 0 & 2 & 1 & 2 & 1 & 1 & 0 & 0 & 0 & 1 & 0 \\
\hline Instrument innovation & 2 & 2 & 3 & 3 & 1 & 1 & 2 & 1 & 6 & 4 & 5 & 3 & 3 & 3 & 2 & 0 & 0 & 0 \\
\hline Systeminnovation & 1 & 1 & 1 & 0 & 0 & 0 & 1 & 1 & 3 & 1 & 3 & 2 & 3 & 1 & 3 & 1 & 5 & 1 \\
\hline Management innovation & 1 & 1 & 3 & 3 & 0 & 0 & 2 & 2 & 2 & 2 & 1 & 1 & 7 & 6 & 0 & 0 & 2 & 2 \\
\hline
\end{tabular}

Note: In the attribute of innovation, A represents the number of sum of financial original innovation events plus diffusion innovation events, that is, the total number of innovation events and $\mathrm{B}$ represents the number of original financial innovation events.

Table A2. The number of financial innovation events and original financial innovation events in 1979-2015.

\begin{tabular}{|c|c|c|c|c|c|c|c|c|c|c|c|c|c|c|c|c|c|c|c|c|}
\hline \multirow{2}{*}{$\begin{array}{l}\text { Year } \\
\text { Innovation attribute }\end{array}$} & \multicolumn{2}{|c|}{1997} & \multicolumn{2}{|c|}{1998} & \multicolumn{2}{|c|}{1999} & \multicolumn{2}{|c|}{2000} & \multicolumn{2}{|c|}{2001} & \multicolumn{2}{|c|}{2002} & \multicolumn{2}{|c|}{2003} & \multicolumn{2}{|c|}{2004} & \multicolumn{2}{|c|}{2005} & \multicolumn{2}{|c|}{2006} \\
\hline & $\mathbf{A}$ & B & $\mathbf{A}$ & B & $\mathbf{A}$ & B & $\mathbf{A}$ & B & $\mathbf{A}$ & B & $\mathbf{A}$ & B & $\mathbf{A}$ & B & $\mathbf{A}$ & B & $\mathbf{A}$ & B & $\mathbf{A}$ & B \\
\hline Financial innovation & 16 & 11 & 6 & 2 & 27 & 13 & 15 & 11 & 17 & 14 & 17 & 9 & 23 & 12 & 45 & 28 & 32 & 17 & 23 & 13 \\
\hline Institutional innovation & 3 & 1 & 3 & 1 & 7 & 2 & 4 & 2 & 6 & 5 & 3 & 2 & 5 & 3 & 8 & 5 & 9 & 3 & 3 & 0 \\
\hline Market innovation & 2 & 1 & 0 & 0 & 0 & 0 & 0 & 0 & 1 & 1 & 2 & 0 & 1 & 1 & 2 & 1 & 0 & 0 & 0 & 0 \\
\hline Instrument innovation & 4 & 4 & 0 & 0 & 4 & 2 & 4 & 3 & 5 & 5 & 4 & 1 & 7 & 4 & 19 & 13 & 6 & 2 & 11 & 9 \\
\hline System innovation & 3 & 2 & 1 & 0 & 8 & 5 & 1 & 1 & 2 & 1 & 4 & 4 & 7 & 3 & 5 & 2 & 7 & 6 & 5 & 2 \\
\hline Management innovation & 4 & 3 & 2 & 1 & 5 & 3 & 5 & 4 & 3 & 2 & 4 & 2 & 3 & 1 & 9 & 5 & 8 & 4 & 2 & 0 \\
\hline
\end{tabular}

Table A2. Continued.

\begin{tabular}{|c|c|c|c|c|c|c|c|c|c|c|c|c|c|c|c|c|c|c|}
\hline \multirow{2}{*}{$\begin{array}{l}\text { Year } \\
\text { Innovation attribute }\end{array}$} & \multicolumn{2}{|c|}{2007} & \multicolumn{2}{|c|}{2008} & \multicolumn{2}{|c|}{2009} & \multicolumn{2}{|c|}{2010} & \multicolumn{2}{|c|}{2011} & \multicolumn{2}{|c|}{2012} & \multicolumn{2}{|c|}{2013} & \multicolumn{2}{|c|}{2014} & \multicolumn{2}{|c|}{2015} \\
\hline & $\mathbf{A}$ & B & $\mathbf{A}$ & B & $\mathbf{A}$ & B & $\mathbf{A}$ & B & $\mathbf{A}$ & B & $\mathbf{A}$ & B & $\mathbf{A}$ & B & $\mathbf{A}$ & B & $\mathbf{A}$ & B \\
\hline Financial innovation & 24 & 15 & 12 & 8 & 27 & 12 & 22 & 14 & 19 & 15 & 3 & 2 & 22 & 14 & 11 & 8 & 18 & 5 \\
\hline Institutional innovation & 6 & 5 & 2 & 2 & 8 & 1 & 4 & 4 & 3 & 0 & 0 & 0 & 1 & 0 & 1 & 1 & 2 & 2 \\
\hline Market innovation & 1 & 0 & 0 & 0 & 2 & 2 & 1 & 0 & 0 & 0 & 0 & 0 & 1 & 0 & 1 & 0 & 0 & 0 \\
\hline Instrument innovation & 5 & 3 & 3 & 3 & 7 & 5 & 7 & 4 & 6 & 6 & 1 & 1 & 8 & 5 & 2 & 2 & 1 & 1 \\
\hline System innovation & 7 & 3 & 1 & 0 & 7 & 2 & 4 & 3 & 2 & 2 & 1 & 0 & 4 & 2 & 2 & 1 & 13 & 0 \\
\hline Management innovation & 2 & 1 & 3 & 0 & 1 & 0 & 4 & 1 & 7 & 6 & 1 & 1 & 7 & 6 & 4 & 4 & 1 & 1 \\
\hline
\end{tabular}

Note: ibid

\section{References}

[1] Zhou Xiaochuan. The Development of Financial Reform AndIts Internal Logic [J]. Journal of Financial Research, 2015, 19: $11-17$.

[2] Li Jian. Structural Problems in China's Financial Development [M]. Beijin: China Renmin University Press, 2004.

[3] Abiad A, Mody A. Financial Reform: What Shakes It? What Shapes It? [J]. The American Economic Review, 2005, 95 (1): 66-88.

[4] Li Jian. Research on the Driving Force of China's Financial Development [J]. Journal of Financial Research, 1998, 7: 1-8.

[5] Finnerty J D. Financial Engineering in Corporate Finance: An Overview [J]. Financial Management, 1988, 17 (4): 14-33.

[6] Silber W L. The Process of Financial Innovation [J]. American Economic Review, 1983, 73 (2): 89-95.

[7] Persons J C, Warther V A. Boom and Bust Patterns in the Adoption of Financial Innovations [J]. Review of Financial Studies, 1997, 10 (4): 939-967.

[8] Bandiera, Oriana; Caprio, Gerard; Honohan, Patrick and Schiantarelli, Fabio. Does Financial Reform Raise or Reduce
Saving? [J]. Review of Economics and Statistics, 2000, 82 (2): 239-263.

[9] Kaminsky G L, Schmukler S L. Short-Run Pain, Long-Run Gain: Financial Liberalization and Stock Market Cycles [J]. Review of Finance, 2008, 12 (2): 253-292.

[10] Ben-Horim M, Silber W L. Financial innovation: A linear programming approach [J]. Journal of Banking \& Finance, 1977, 1 (3): 277-296.

[11] Sametz, Arnold W. The new financial environment of the United States. In Edward I. Altman (ed), Handbook of Financial Markets and Institutions, 6th edn. John Wiley and Sons, New York, 1987.

[12] Krueger, Anne O. Political Economy of Policy Reform in Developing Countries [M]. Cambridge: MIT Press, 1993.

[13] Lora, Eduardo and Olivera, Mauricio. What Makes Reforms Likely: Political Economy Determinants of Reforms in Latin America [J]. Journal of Applied Economics, 2004, 7 (1): 99-135.

[14] Haggard, Stephan and Webb, Steven B. What Do We Know about the Political Economy of Economic Policy Reform? [J]. World Bank Research Observer, 1993, 8 (2): 143-168.

[15] La Porta, Rafael; Lopez-de-Silanes, Florencia; Shleifer, Andrei and Vishny, Robert. Legal Determinants of External Finance [J]. Journal of Finance, 1997, 52 (3): 1131-1150. 
[16] Levine, Ross; Loayza, Norman and Beck, Thorsten. Financial Intermediation and Growth: Causality and Causes [J]. Journal of Monetary Economics, 2000, 46 (1): 31-77.

[17] Rajan, Raghuram G. and Zingales, Luigi. The Great Reversals: The Politics of Financial Development in the Twentieth Century [J]. Journal of Financial Economics, 2003, 69 (1): 5-50.

[18] Ang J B, Kumar S. Financial Development and Barriers to the Cross-Border Diffusion of Financial Innovation [J]. Journal of Banking \& Finance, 2014, 39 (1): 43-56.

[19] Wu Jinglian. Bank Reform: the Most Important Part of China's Current Financial Reform [J]. China Economic Weekly, 2002, 12: 15-19.

[20] Li Yang. China's Financial Reform And Opening up in the Past 30 Years: History, Achievements And Further Development [J]. Economics of Finance And Trade, 2008, 11: 38-52.

[21] Wei Shangjin. The Main Points of China's Financial Reform [J]. Chinese Finance, 2015, 2: 12-14.
[22] Wang Guangqian. An Analysis of Structural Problems in China's Financial Development [J]. Journal of Financial Research, 2002, 5: 47-56.

[23] Wang Renxiang, Yang Man. Research on China's Financial Innovation Quality Indexes: Based on "Technology-Finance" Paradigm [J]. World Economy Studies, 2015, 7: 3-13.

[24] Laeven, Luc. Does Financial Liberalization Reduce Financing Constraints? [J] Financial Management, 2003, 32 (1): 5-34.

[25] Wang Shuo, Zhang Jiwei, Hawkan. An Exclusive Interview with Zhou Xiaochuan-Central Bank Governor Zhou Xiaochuan Talks about RMB Exchange Rate Reform, Macro-prudential Policy Framework and Digital Currency [J]. Caixin Weekly, 2016, (6): 52-61.

[26] Zhou Xiaochuan. The Prospect And Path of RMB Capital Account Convertibility [J]. Journal of Financial Research, 2012, (1): 1-19. 